\title{
تقنيات التعريف
}

في معجم ما استُعجم من أسماء البلاد والمواضع تأليف: عبد الله بن عبد العزيز البكري الأندلسي

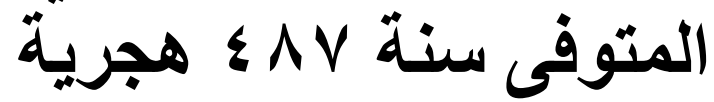

حقّقه وضبطه: مُصطقى السيّةًا

(در اسة في كيفية المعالجة)

\author{
الإباحثة \\ فوزيــة الحسيني
}




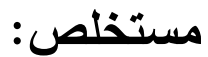

تسعى هذه الدراسة إلى محاولة الوقوف على كيفية تعريف المدونة

اللغوية عند البكري في معجمه الموسوم بـ لمعجم ما استعجمه في تنويب يتتاول: ما قدّمه المعجم من معلومات حول المادة المعجمية، وما اعتمده من بن وسائل تعريف الألفاظ، وما استخدمه من التقنيات والخطوات الإجرائية في شرح النماذج المختارة من مدونته. وتخلُص الدراسة إلى اعتبار معجم ما استعجم للبكري لم تقتصر وظيفته على إعانة الدارسين في أمن اللبس من التصحيف والتحريف في أسماء المواضع والبلدان - تلكك الوظيفة التي كانت هدفاً للبكري عند إعداد معجمه بل تعدتها ليكون معجماً لغوياً خاصاً بتحقيق أسماء المواضع معتمداً وسائل

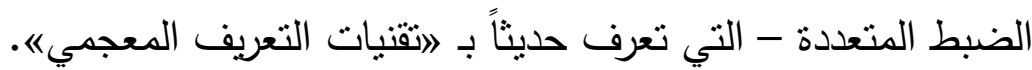

الكلمات المفتاحية : - المية أمن اللبس ، التصحيف ، التحريف ، استعجم ، التعريف المعجمي. 


\section{Methods of Providing Definition in Glossary of "Ma Istagam" Unclear Meanings}

\section{Abstract:}

This study attempts to identify how to define linguistic corpus by Al-Bakri in his glossary, known as Glossary of "Ma Istagam" Unclear Meanings, in terms of the chapters: what the glossary provided in terms of information on the glossary entry; what it adopted in terms of the methods of defining words; and what it used in terms of the techniques and operational steps to explain the chosen entries in his corpus.

This study concludes that Glossary of "Ma Istagam" Unclear Meanings of Al-Bakri is not limited to defining unclear meanings in terms of removing distortion of the names of things and places - that was Al-Bakri's task when preparing the glossary - but it goes beyond that to be purely linguistic glossary, to mention the names of things correctly, depending on multiple techniques of verification, recently known as "techniques of glossary definition".

\section{Keywords:}

Confusion, defamation, distortion, lethargy, lexical definition. 


\section{المقدمة}

يعتبر معجم ما استعجم للبكري نصنَّا لغوياً، نازحاً عن ساحته، مغترباً عن عصره، وهو أثز نفيس يمثل النضج العقلي، والارتقاء العلمي العربي، فلا يُكاد يُرى له نظير في معاجم البلدان، تمام ضبط، وجمال أسلوب، وتحرير عبارة.

اعتمد عليه كثثر من العلماء، والمحدثين، والإخباريين، أثهرهم القاضي عياض، في مشارق الأنوار، والسهيلي في الروض الأنف(*)، ومن المعجميين: الفيروز أبادي في القامس والزبيدي في تاج العروس والفاسي في الحاثية على القي القاموس، وغيرهم"'. يقول المستشرق الهولندي دُوزي، مشيداً بمكانته: „إن

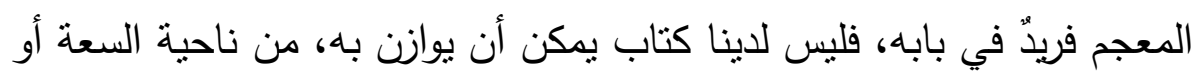
من ناحية دقة التقاصيله (؟). عُني مؤلفه أثند العناية بضبطه، فاختص بالدقة في الضبط والتوثيق، وهو يعوّل في تعريف مادته على تقنيات متعددة منها ما يتعلق بمبنى اللفظ، ومنها ما يتعلق بمعناه، فقام sعجمه على تتاول البحث الجغرافي من الواقع اللغوي، بالضبط والتصحيح. التعريف بمؤلف المعجم:

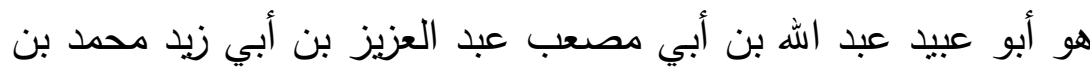
أيوب بن عمرو البكريّ، لغوي أندلسي، امتاز عن أهل عصره بثقافته اللغوية العالية.

(*) ينظر على سبيل المثال، ص10 1) 》دومة الجندله.

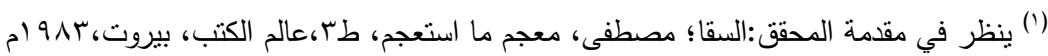


كان والده آخر البكربين حكماً بـ أَوْنَبَه(*) لاوَلْبَه| على ساحل البحر غربي

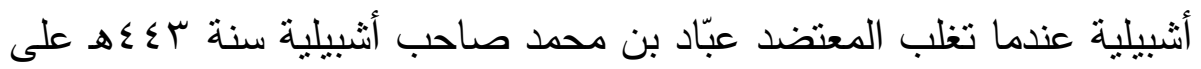
ما جاوره من البلاد والإمارات، فخرج هو وآله منها، ونزلوا قرطبة في كنف بن

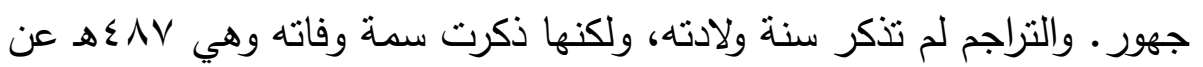
سن عالية(')

والبكري ورث ثقافة القالي (ץ)، واستطاع بثقافته شرحها والاستدراك عليها

نحو: اللآلىئ في شرح أمالي القالي. يقول ابن بشكوال في كتاب الصلة، في التعريف به: 》اكان من أهل اللغة ،والآداب الواسعة ،والمعرفة بمعاني الأشعار،

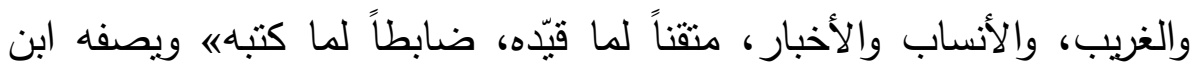
بسّام 》الثنتريني" في الذخيرة بقوله: »... كأن العرب استخلفته على لسانها والأيام ولَّتها زِمام حدثاتهاه.

التعريف بالمعجم: 》هعجم ما استعجم من أسماء البلاد والمواضع « يصنّف هذا المعجم في علم الجغرافيا لكنه يكتسي بردة المعجم اللغوي.

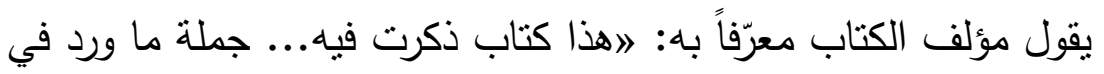
الحديث والأخبار ... ثم يقول: فإني لما رأيت ذلك قد استعجم على الناس والتواريخ، والأشعار من المنازل، والديار والقرى، والأمصار، والجبال... أردت

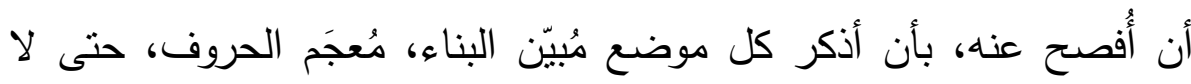

(*) ولبه: Huelva، تقع جنوب غرب إسبانيا عاصمة مقاطعة ولبه في منطقة أندولوسيا على ساحل خليج

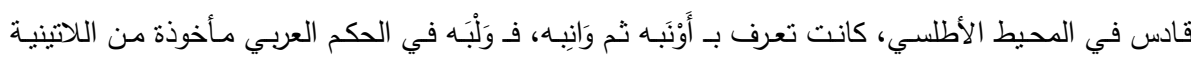
(أُونُوًًََا) ومن الفينيقية (أُونُوس).

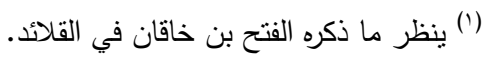

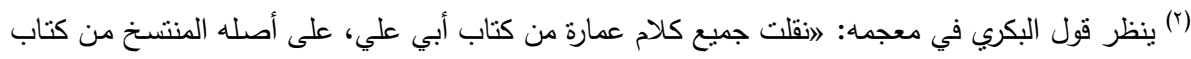
أبي سعيده / / أ. اليكري 
يُدرك فيه لبسُ ولا تحريف" (1).

ثم يستشهد بما ذكره ابن قتنية في طبقات الثعراء حين قال: القُرئ يوماً على الأصمعي في شعر أبي ذؤيب:

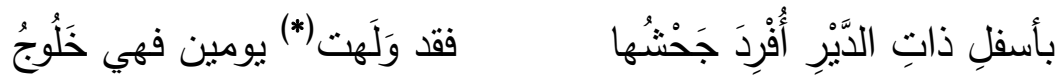

فقال أعرابي حضر المجلس للقارئ: ضلّ ضلالك !إنما هي:ذات الدَّبرِ (*)

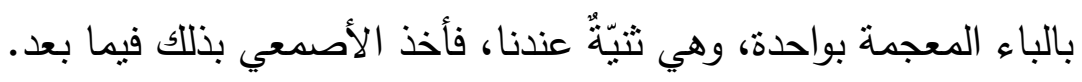
ثم يروي البكري أخباراً عن عِدّة من العلماء، قد اختلفوا في اسم موضع ولم يدروا وجه الصواب فيه، مثل يزيد بن هارون وهو إمام في الحديث، حيث كان يُصحَفُ جُمْدان، وهو جبل بين قُديد وعُسفان، من منازل بين سُليم، فيقول:

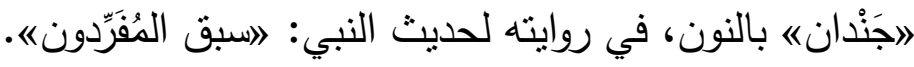
وكذلك جماعة من المحدثين يقولون: الحَزَوََرة: بفتح الزاي، وتتنديد الواو، لموضع يلي البيت الحرام به كانت سوق مكة، حيث بروون قوله: اواله إنك

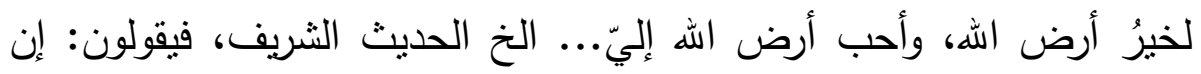
رسول الله وقف بالحَزَوَّرَةه، وإنما هي الحَزْوَرَة بالتخفيف، ولا يجوز غيرها.

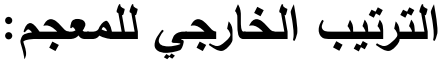

رثب البكري معجمه بترتيب الحروف الهجائية عند أهل المغرب(؟) وهو ترتيب غير مألوف عند المشارقة، لاختلاف نرتيب الحروف الهجائية في

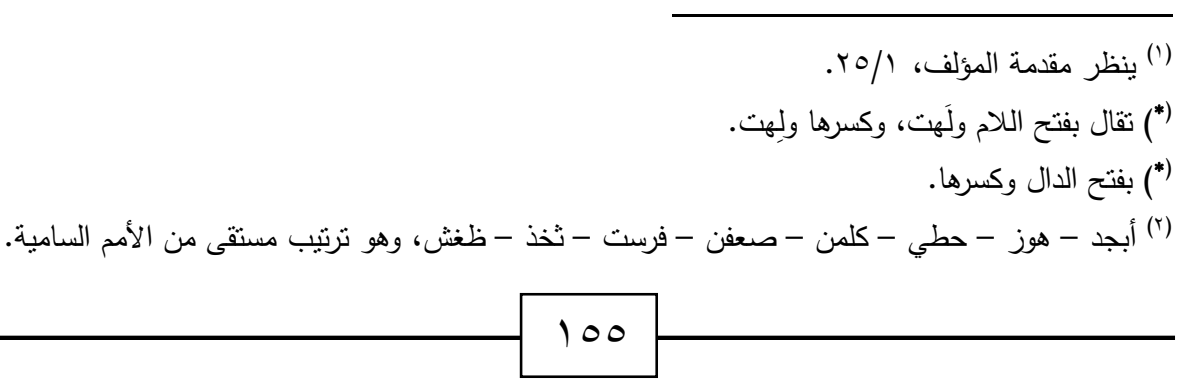


المغرب عنها في المشرق(')، فكان مصدر عناء للباحثين وعلى الرغم من ذلك، تلقى العلماء قديماً وحديثاً معجم البكري بالقبول ونال مكاناً علياً، واعتمد عليه

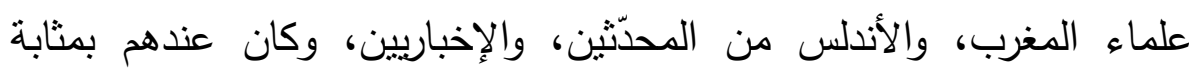
المرجع الذي يُعتمد عليه، في تحقيق المشكلات. ونظراً لنفاسة هذا المعجم وقيمته العلمية، قامت لجنة التأليف والترجمة، والنشر، المعنية بنشر نفائس المخطوطات والكتب، برئاسة الأستاذ أحمد أمين بك، بإسناد تحقق هذا الكتاب وترتيبه، إلى الأستاذ: مصطفى السّقا(*). فقام بتغيير وضع مادته، ورتّبها على حسب ترتيب حروف الهجاء في المشرق، وعلى ما يقتضيه نظام الفهرسة الصحيح، فرتب حروفها بحسب صورتها، لا بحسب جوهرها، ومادّتها، يقول مصطفى السقا شارحاً طريقته: ا(فليس مما

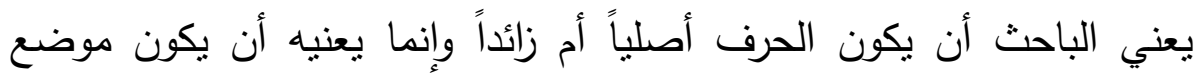

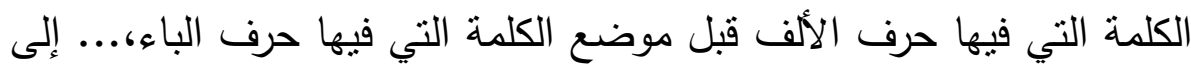
أن يقول:كما يعنيه هذا الترتيب في الأحرف التي بعد الحرفين الأولينه(؟).

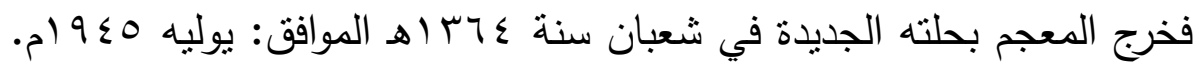

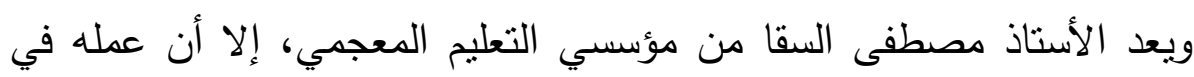
تغيير ترتيب مادة معجم ما استعجم لم يكن موفقاً، لأن البكري كثيراً ما يميل إلى مادة كتابه فيقود هذا التغيير إلى إحداث مشكلة في الإحالة(*)، وفي المنهج (1) أبجد - هوز - حطي - كلمن - سعفن - فرشت - تخذ - ضظغ، الاختلاف يقع في ترتيب السين والثين، والثناء والثاء، والضاد والظاء والغين.

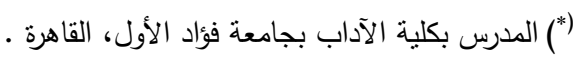

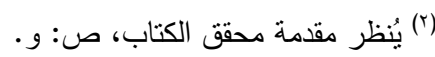

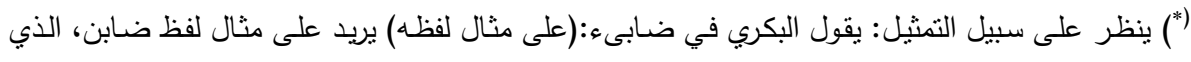

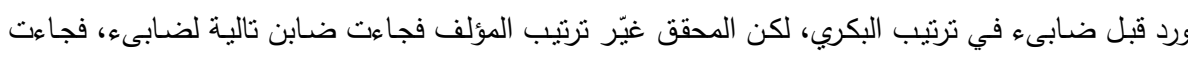

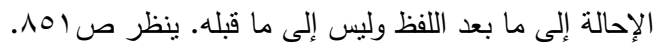


القديم للكتاب، وكان من الأنجع في طلب نسهيل عملية الترتيب عمل فهرس في آخر الكتاب يُشنار فيه إلى الاختلاف.

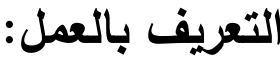

البكري أديب وجغرافي جدير بما قدمه من معلومات صحيحة وواضحة من حيث الضبط، ومن حيث المعلومة، فقد بين حدود بلاد العرب وأقسامها الجغرافية، وأرّخ للقبائل العربية تتقلاتهها، ووقائعها، وأيامها. وانعكست مدونة البكري الثقافية واللغوية على مادته المعجمية، فجاءت غنية بوسائل التعريف المختلفة. فقد اعتمد البكري في الجانب التحليلي لمادته المعجمية على الثرح بالتعريف بكافة صوره، وكانت وسائله كثيرة، ومتعددة طبقها على جميع مواد

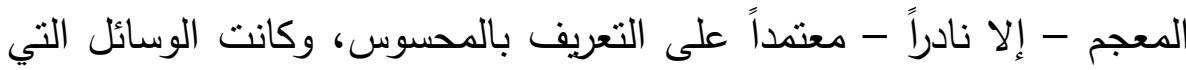
استخدمها شائعة في كل مواد المعجم الذي التزم فيه فنيّات ضبط الرسم ثم شرحه، باستخدام الوسائل المتعلقة بالمبنى، وبالمعنى، ثم قرن ذلك بالثاهد معزواً لصاحبه.

وكان اقتران التعريف بالثاهد غاية ما انتهت إليه منهجيته في الضبط.

ولم يكتفِ البكري بتتوّع وسائل التعريف في معجمه، بل كان يذكر المواضع مقترنة بكل الأحداث، والأخبار، والقصص التي ارتبطت بها، في ترابط منوازٍ، وبلغة عليا تتناسب مع الزمان الذي صنع فيه معجمه، فخرج المعجم من جمود اللغة إلى بعث الحياة داخلها، من خلال مواكبة اللغة للحدث.

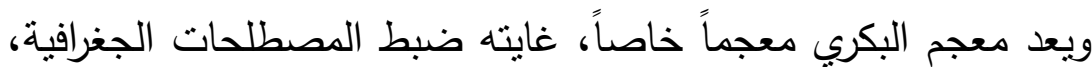
وأمن اللبس في نطقها، إلا أنه اكتسب لوناً لغوياً خاصاً، طغى على لغته، فكان من وجهة اللغة أقرب منه، من وجهة الجغرافيا، فجاء العمل المعجمي الذي قام به على درجة عالية من المصداقية العلمية، التي يتحرّاها مستخدم المعجم، أو الباحث اللغوي. 
وعليه، فدراسة كيفية معالجة تعريف مدونته المعجمية، يُعدّ من الدراسات اللطيفة التي تجمع بين بُعد المتتاول، (البحث الجغرافي) وقُرب الواقع (الضبط

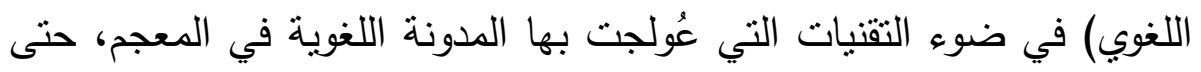
تُستجلى تلك التقنيات. وستكون هذه المعالجة في نماذج مختارة، تتمثل فيها ما أمكن- جميع التقنيات التي اعتمدها في مدونته. وتقع هذه الدراسة في ثلاثة فصول يسبقها تمهيد يشرح الغرض منها والنقاط التي ستتناولها.

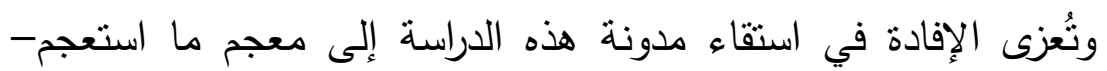

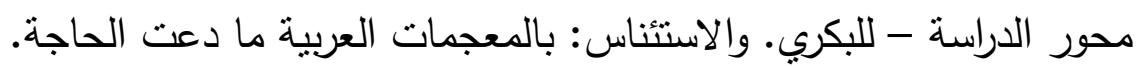
واسترفاد المعلومات المعينة من بعض المراجع ذات العلاقة، نحو: اللغة العربية: معناها ومبناها تمام حسان، علم اللغة وصناعة المعجم، د. علي القاسمي، المعاجم اللغوية، محمد أبو الفرج، من قضايا المعجم العربي، محمد رشاد الحمزاوي. ومحاضرات الدكتور عبدالحميد الأقطش (نصوص في اللغة) برنامج الدكتوراه/ كلية اللغة العربية/ جامعة أم القرى، وغيرها من المراجع التي تستدعيها حاجة الدراسة.

\section{تمهيد: تعريف المادة المعجمية:}

يقصد بتعريف المادة المعجمية ما يقدمه المعجم من معلومات حول

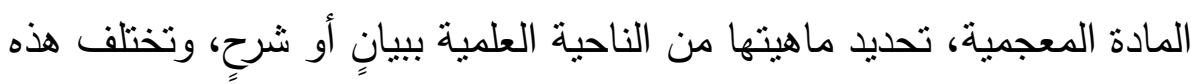

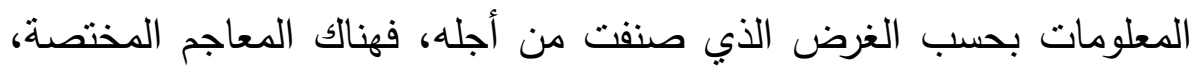
والمعاجم الموضوعية،وكذلك معاجم الأبنية،ومعاجم الألفاظ، وغيرها من الن المعاجم الأخرى. والتفسير المعجمي يشكّل أهمية بالغة في التعريف بالمادة المعجمية وعليه يتوقف فهم المعنى،سواء من ناحية المبنى،أم من ناحية 
المعنى (')

وقد تبارى المعجميون في عملية الجمع إلى الحد الذي أصبح المعجم العربي ضرباً من الموسوعات الهائلة، تختلط فيها اللغة: بالأدب، وبالتاريخ

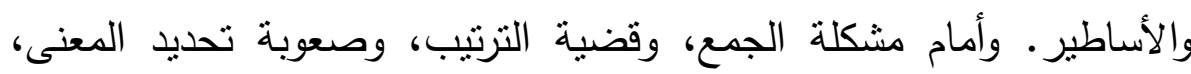
وتغيره وتطوره، غاية توخّاها أصحاب المعجمات، وهي تونثق المادة المعجمية. ولعل هاجس توثثق المادة يبدو جلياً، من خلال مسميات معجماتهم، نحو: البارع، المحكم، التهذيب، الصحاح، والتي توحي معنى الدّقة، والتتبت. فالمعجمي بشعر أمام اللفظة بما يشعر به، راوي الحديث، لا ينطق

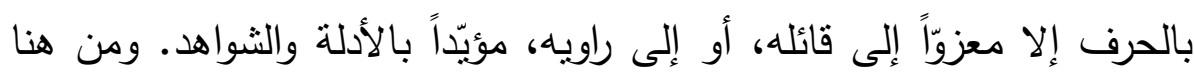
تتوّعت أساليبهم في معالجة الألفاظ من السياق اللغوي، والمقامي، إلى تدقيق أدواتهم في عملية الثرح والتقسير فتعددت وسائل التدقيق، والضبط، والتوثيق، في المعجمات، أذكر منها على سبيل التمثيل (ז) 1- الضبط بالسياق: ويُعبّر عنه بما يدل عليه السياق سواء كان سياقاً لغوياً أم مقامياً. r- الضبط بالمصاحبة: ويُعبّر عنه بما يصحب الكلمة من كلمات هي جزء من معناها الأساسي. r- الضبط بالمغايرة: ويعبر عنه بلفظ: نقيض، أو ضده، أو خلاف. ع - الضبط بالمماثلة: ويعبر عنه بلفظ: مثل، أو الجمع بالواو . 0- الضبط بالترادف: ويعبر عنه بلفظ كله بمعنى واحد.

(') يُنظر في تحليل المادة المعجية: الثبيتي، د.محمد بن سعيد، ص • r، الموسوعة الثـاملة، مجلة أم القرى، لئل بدون بيانات.

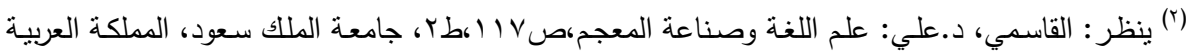

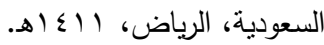


T- الضبط بالترجمة: ويعبر عنه بشرح المعنى بكلمة أو كلمات من اللغة

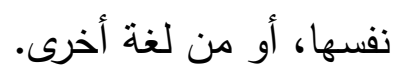

V- الضبط بوسائل الإيضاح: ويعبر عنه باللون، أو الصورة وهذه الوسيلة من

$$
\text { وسائل الضبط الحديث( ( ). }
$$

ومعجم ما استعجم للبكري، من المعاجم المختصّة، فهو معجم جغرافي، في أسماء البلاد والمواضع، يقول عنه مؤلِّهه بعد أن رأي استعجام أسماء

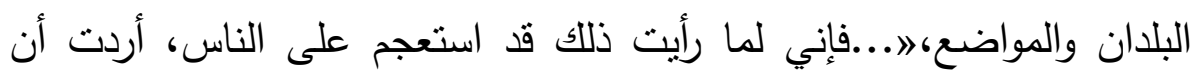
أفصح عنه، بأن أذكر كل موضع مُبيَّن البناء، مُعجَم الحروف حتى لا يُحْرَك

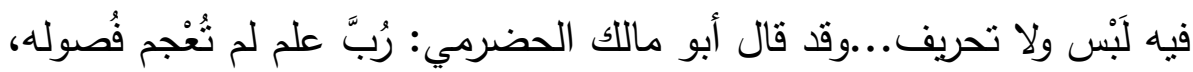

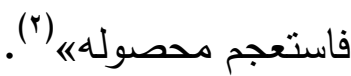
وعند مطالعة المعجم، وُجد صاحبه لم يجاوز ما ذكره، من ضبط وتوثيق للأسماء، وصل به إلى فنيّات الضبط، وتقنيات التعريف. وهنا استحضر عبارة قيلت في حق هذا المعجم (يعتبر معجم ما استعجم للبكري نصّاً لغوياً، نازحاً عن ساحته، مغترباً عن عصره، وهو أثز نفيس يمثل النضج العقلي، والارتقاء العلمي العربي، فلا يكاد يُرى له نظير في معاجم البلدان، تمام ضبط، وجمال أسلوب، وتحرير عبارة)(*). فكانت تلاك العبارة، إثارة إلى أنه من الواجب أن أن يأخذ هذا الجهد وصاحبه حقه من الاعتراف بجليل العمل، وسلامة المتتاول،

(1) ينظر : أبو الفرج، محمد أحمد: المعاجم اللغوية في ضوء دراسات علم اللغة الحديث، ص ا ـ ا، طا، دار النهضة العربية، 97 (م. وينظر : الوسيط، مجمع اللغة العربية، القاهرة، دون تاريخ.

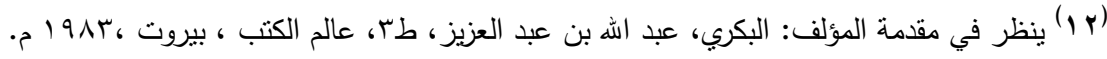

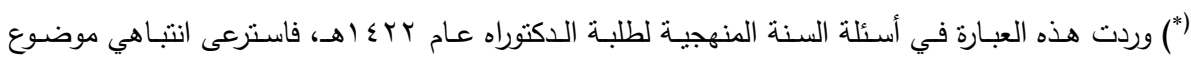

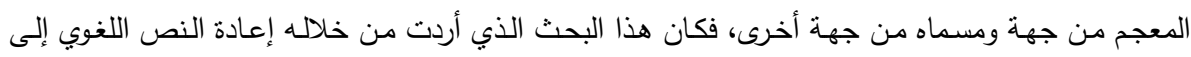
ساحته ووضع حدٍ لغربته. 


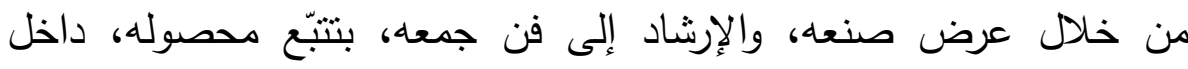
فصوله، فكانت هذه الدراسة في كيفية معالجة تعربف المداخل المعجمية في معجم ما استعجم للبكري.

\section{وسائل تعريف المادة المعجمية في معجم ما استعجم للبكري:}

يُقصد بتعريف (تحليل، شرح) المداخل المعجمية ما يقدمه المعجم من

معلومات حول تلك المداخل("). والتحليل توظيف اللغة إلى أقصى حدٍ في مي التفسير والتوضيح(؟) . وضبط المادة المعجية من الأساليب -الإجراءات- التي

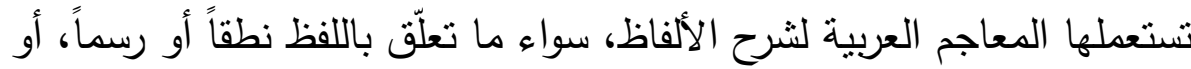
ما تعلّق بالمعنى وضوحاً، وأمن لبس. واختلف المعجميون القدماء في الاهتمام بهذا الجانب من الدرس اللغوي،

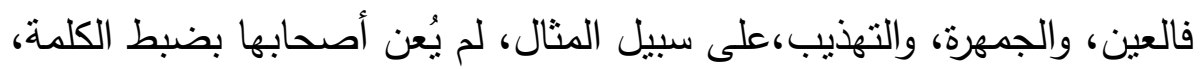
ولم يكن الضبط سمة بارزة لمعجماتهم. ولعل ذلك عائد إلى السياق الاجتماعي الذي يؤدي إلى ضبط الكلمة في عصرهم("). أما من جاء بعدهم من بارة المتأخرين، فقد اهتموا بهذا الجانب، ورأوا ضرورته، والحاجة إليه في ضبط الألفاظ، وأول من اهتم بالضبط من القدماء والمتأخرين- فيما أعلم- القالي في مصنفه الموسوم ب»البارع في اللغةه، ثم الجوهري في:»الصحاح) ويليه الفيروز أبادي في: 》القاموس المحيط《.

اعتمد القدماء في ضبط المدخل على أمور عدة، منها: ما يتعلق بضبط الكلمة من حيث طريقة النطق، ومن حيث تحديد الرسم الإملائي أو الهجائي،

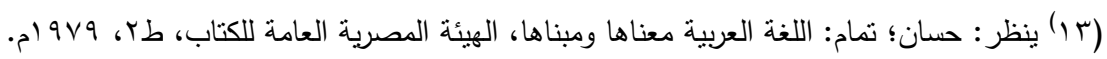

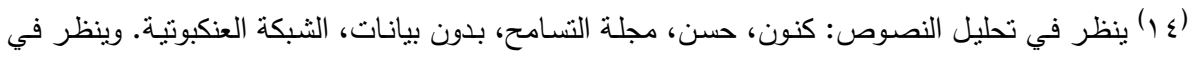

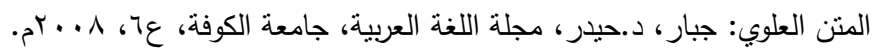

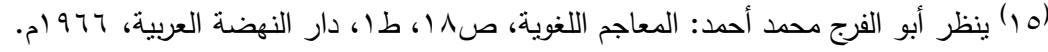


وعالجوه بعدة طرق (')، نحو : الضبط بالنص، والضبط بالعبارة، الضبط بالوزن أو المثال. الضبط بالإعجام. ومنها ما يتعلق بضبط المدخل من الناحية الصرفية والنحوية واللغوية، وذللك بتقديم بعض المعلومات التي تسهم في فهم الكلمة وتوضيحها نحو : التصريف، الاشتقاق، التعدي واللزوم، عدم الاستعمال، الجمود، الإفراد والجمع، الجنس، النسب، بيان المحذوف، درجة الاستعمال، اللغات 》الفصاحة وعدمها《. ومنها ما يتعلق بضبط المدخل من الناحية الدلالية؛ إذ يمثل المعنى أكبر صعوبة يواجهها صانع المعجم، وذلك لأمور أهمها: صعوبة تحديد المعنى، وسرعة التطور والتغيير فيه، واعتماد تقسيره على جملة من القضايا التي تتعلق بمناهج دراسة المعنى، وشروط التعريف، وعوامل التطور الدلالي والتمييز بين المعاني المركزية والهامشية وغيره(؟). وعلى ضوء ذلك تتعدد وسائل تعريف المعنى، في المعاجم عامة، والعربية خاصة، ومن وسائل الثرح والتوضيح بالمعنى:الثرح بالتعريف بالألفاظ

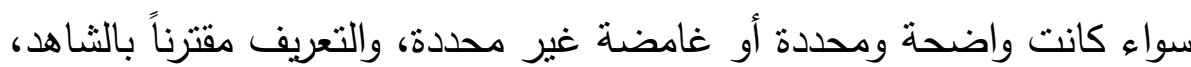

لما يمثله من قيمة ومصداقية يتحرّاها الباحث في المعجم المستخدم له (ب). ويتّهم المعجميون المعاصرون المعجمات القديمة، بالقصور في تأدية

المعاني والمفاهيم العلمية الحديثة، فهي لا تفي بالمعايير العلمية إن اعتبر بانير

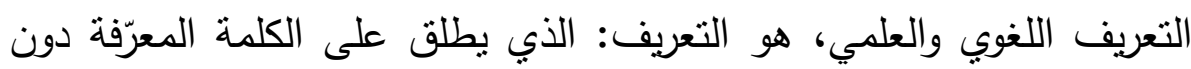

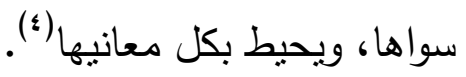
ويستوجب المعجم أن يعرّف بحسب طبيعة المعلومات التي يوفرها عن

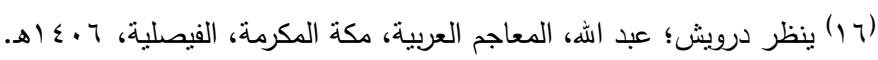

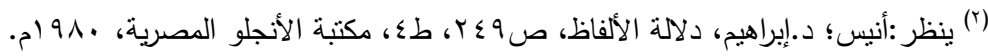

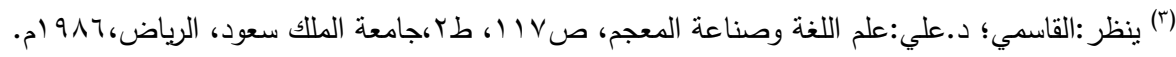

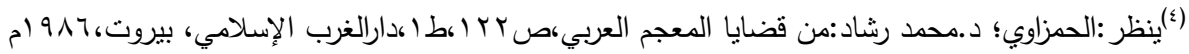


اللفظ - المادة - أو ما بسمى المدخل. والمعجمية العربية أتت بنظريات طريفة لم تتملها الدراسات اللغوية العالمية، التي تهتم بالمعجم وقضاياه، ولعل ذلك عائد إلى جهل الدارسين بمساهمة المعجمين العرب في تطوير المعجم ('). ومن خلال الخطوات الإجرائية التي اتبعها البكري في التعريف بالرصيد

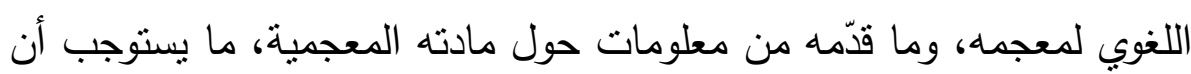
يُعرف إلى أي مدى أسهم ذللك في الكثف عن فنيّات البحث اللغوي القديم سواء من ناحية مبنى اللفظ أو ناحية معناه.

\section{الفصل الأول: وسائل التعريف التي تتعلق بمبنى اللفظ:}

بنى البكري مداخل معجمه على الضبط والتوثيق، بكل صوره، وأثنكاله، وبالغ في هذا الضبط، الأمر الذي جعل اللفظ الواحد يحفل بعدد من وسائل الضبط المختلفة، وقلّما وُجد لفظ في معجم ما استعجم لا يحوي سوى وسيلة واحدة للضبط، تتمثل في ضبط رسمه الإملائي والهجائي. والضبط عند البكري أمر في غاية الأهمية فهو يمثل البؤرة التي بنى عليها معجمه، وعلى أساسها

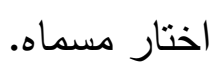

والتعريف من أهم الوسائل الإجرائية الحديثة التي تتعلق بتحليل المادة

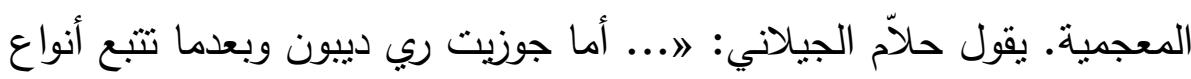
التعريفات... كثيراً ما يستخدم التعريف الاثتقاقي، وبخاصة في الألفاظ المجردة، وبذلك يعيد لفظاً من ألفاظ المعرّف في التعريفه 》استنطقه: أي جعله ينطقه وذللك إما عن طريق السياق، وإما عن طريق الإحالة، وإذا كانت هذه القضية مرفوضة في التعريف الأرسطي، فإنها تعتبر ضرورية في التعربف 


$$
\text { المعجمي في كثير من الحالات (1). }
$$

اعتمد البكري في ضبط المداخل في معجمه، فيما يتعلق بالمبنى، وسائل متعددة، ورغم أن الحقل الدلالي الذي بنى عليه معجمه، أسماء المواضع والبلدان (جغرافي)، إلا أنه استخدم كل ما أمكنه من فنيّات الضبط اللغوي، فمن ذلك الضبط النّطقي والثّكلي، وتمنّك في فنيّات عدّة منها:

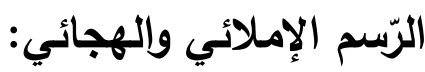

اعتمد فيه البكري على التعريف برسم الكلمة، والتعربف بطريقة نطقها من خلال التعريف بالتشكيل - الحركات - الذي يساعد على ذللك، وتعددت وسائله في ضبط صورة اللفظ، برسم صورته في عبارة أو نصّ، أو ضبط وزنه ومثاله. ولم يكتق البكري بذلك بل بلغ ضبطه للألفاظ، تقديم معلومات صرفيّة ونحوبّة:كالتصريف، والاشتقاق، والجنس، والعدد، والنسبة.... وغيرها. ويتخذ البكري فيما بتعلق بشرح المبنى، فنيّات عدّة تمثّت في:

\section{الخطوات الإجرائية المتعلقة بشرح المبنى:} قدّم البكري فنيّات مختلفة أسهمت في الضّبط النّطقي لمادته، من تلك

الفنيّات:

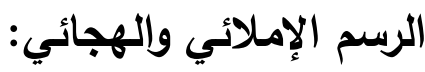

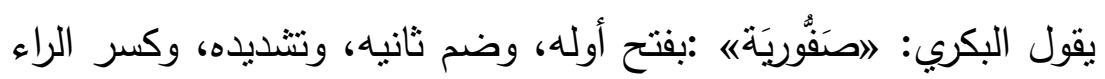

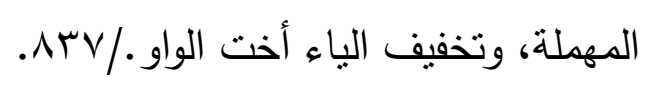

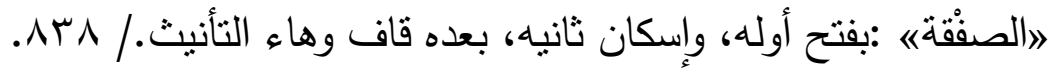

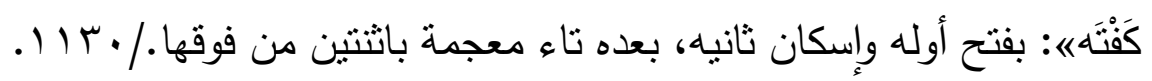
(') ينظر : الجيلاني؛ حلام. تقنيات التعريف في المعاجم العربية المعاصرة جامعة ميتشقان مايو ^... ب 


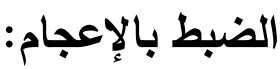

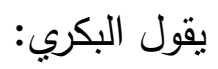

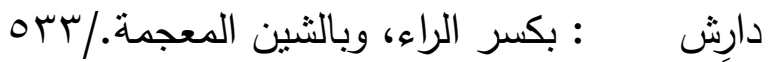

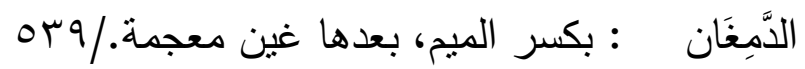

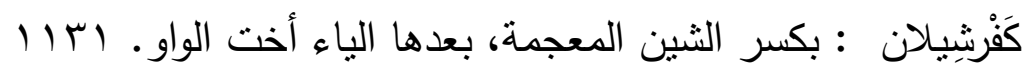

الضبط بالنص أو العبارة: انئن

يقول البكري: - n

دوحة : على لفظ الدّوحة من الثجر . / • 07 الصنّفَاف: على لفظ اسم الثجر .

ضواحي البصرة: جمع ضاحية، وهي أطرافها، وما لا سواد فيه،

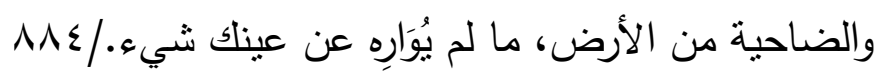

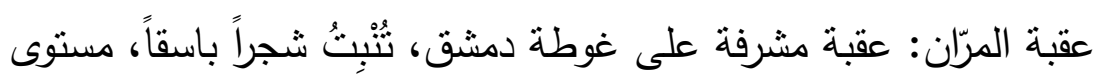
النباتات، تتخذ منه القنا والرماح، وهو المُرَّان./9 9 الضبط بالوزن أو المثال: - مال

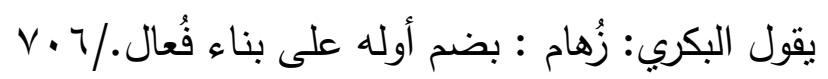

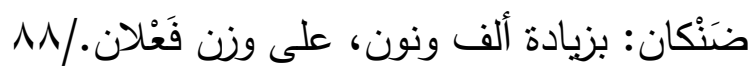

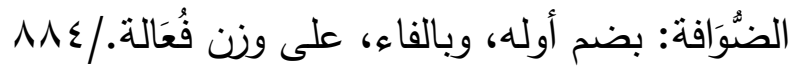

الخلاف في الضبط:

البكري لا يكتفي بالضبط في مادته بل يتعداه إلى الإشارة إلى الخلاف

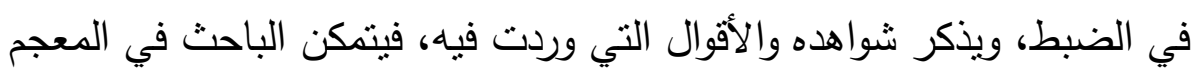

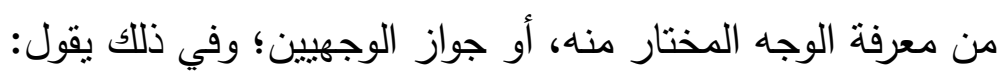
عُوق: بضم أوله، وبالقاف من أرض غطفان. 


$$
\text { وقال أبو عمرو : عَوْق بفتح العين./11) }
$$

ويقول في الذّنانين: الذنانين: بفتح أوله، وبنون بعد الألف، ونون بعد الئه الياء على

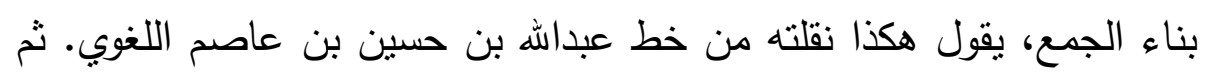

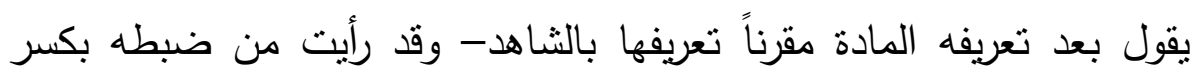

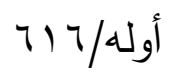

ويقول في الرّميثنة: الرميثنة: بضم أوله على لفظ تصغير رمثة، ويقال له الرِّمث أيضاً./VVT

ويقول في الجِحْرانَة: الجِعِرَانة: بكسر الجيم والعين، وتثنديد الراء المهملة، هكذا

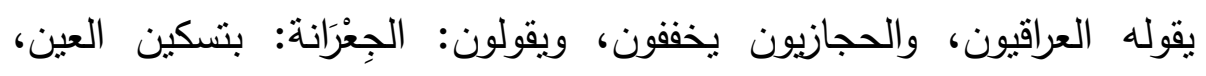
وتخفيف الراء، وكذلك الحديَّيَّة: الحجازيون يخفقون الياء، والعراقيون

$$
\text { بيقتلونها... }
$$

زِكْتَ: بكسر أوله، وإسكان ثانيه، بعده تاء معجمة باثتنتين من فوقها:

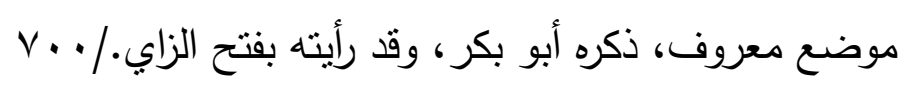

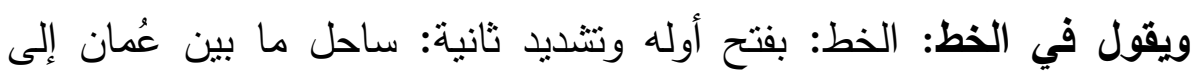
البصرة، ومن كاظمة إلى الثحر •

قال الخليل: إذا نسبت الرماح إليها: قلت رماح خَطيّة، وإذا جعلت النسبة اسماً لازماً، ولم تذكر الرماح قلت: خِطيّة بكسر الخاء، كما قالوا ثياب قبطية،

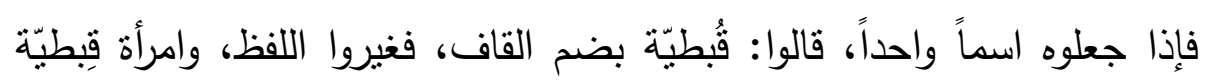

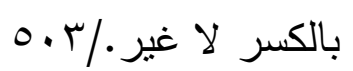

والبكري لم يكتفِ بذكر الخلاف في الضبط، بل ذكر الخلاف أيضاً في التذكير والتأنيث وقد عقد له باباً في آخر معجمه، يقول في دابق: دابق: بكسر الباء مدينة معروفة: في أقاصي فارس، تذكّر ومؤنتّ. 
يقول البكري: فمن ذكّره - من التذكير - جعله اسماً للنهر، ومن أنتَّه -

من التأنيث - قال هو اسم للمدينة، وأثبت التعريف باقتران الثاهد، حيث يقول:

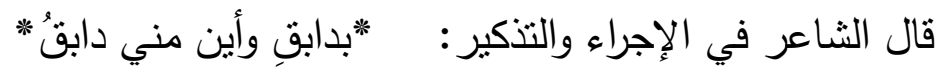
وقال آخر في التأنيث وترك الإجراء:

بدابقَ إذا قيل العدو قريب./. لقد ضاع قوم قَلَُّوك كو أمورهم ويتعدى البكري ذكر الخلاف إلى:

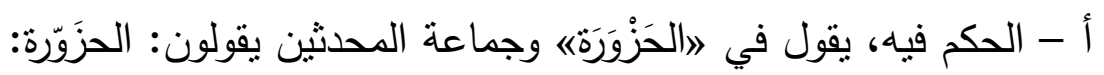
بفتح الزاي وتتديد الواو، لموضع يلي البيت الحرام، وبه كانت سوق مكة، وقد دخل اليوم في المسجد، يروون أن رسول الله عليهوللهم وقف بالحزورة وقال: لاوالله إنك لخير أرض اله، وأحب أرض اله إليّ، ولولا أني أُخرجت منك ما خرجته يقول البكري: وإنما هي الحَزْوَرة: بالتخففيف، لا يجوز غيره، قال الغنوي:

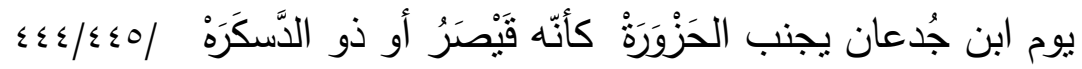
ويقول البكري في بطحان بفتح أوله، وكسر ثانيه، وبالحاء المهملة، على إنى وزن فَعِلان لا يجوز غيره، قال ابن مقبل يرثي عثمان بن عفان رضي الله عنه:

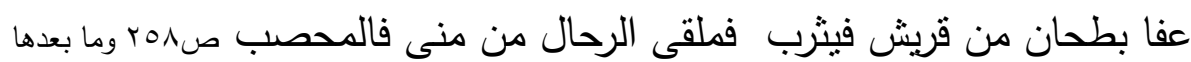

\section{ب - التحقيق والتوثيق به:}

يقول في رسم القاحة: القَاحة: بالحاء المهملة: موضع على ثلاث مراحل من المدينة قبل مكة... ثم ذكر البكري حديث أبي محمد مولى أبي قتادة، حيث يقول قتادة: (افلقيت رجلاً من بني غِفَار في جوف الليل، فقلت أين

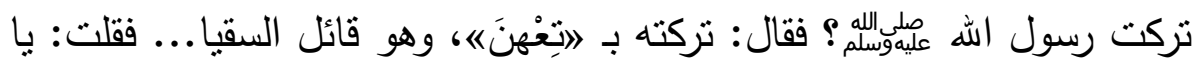
رسول الله إن أصحابك يقرعون عليك السلام، وإنهم قد خشوا أن يقتطعه العدو دونك، فانتظرهم ففعله.

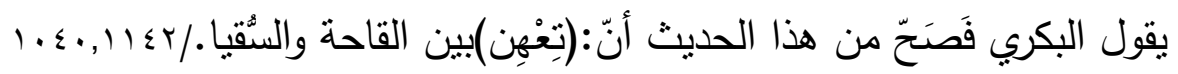


ويقّم البكري فيما يتعلق بشرح المبنى أيضاً معلومات تسهم في فهم

اللفظ، وتوضيحه من خلا الضّبط النّحوي والصّرفي واللّغوي، فمن ذلك:

\section{التّصريف:}

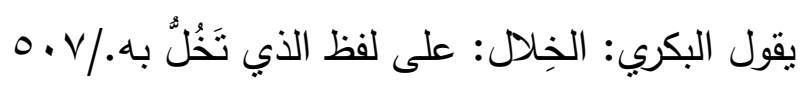

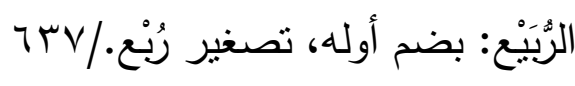

زابن: بالنون على بناء فاعل من زبن./ (9)

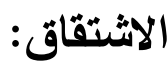

يقول البكري: خَيْنَف: بزيادة نون مفتوحة بين الياء والفاء، من خَيْف. ضاحك: على لفظ فاعل من الضحك./AOr

ظُلامَة: بضم أوله قرية أُخذت ظلماً، فسميت ظُلامة.

وفي: النسب: يقول البكري:

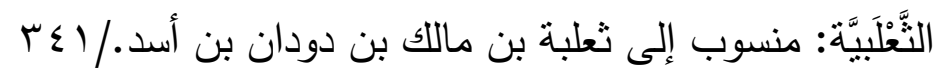

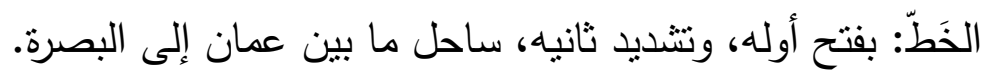

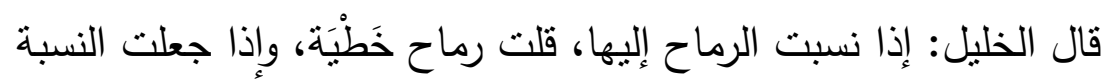

اسماً لازماً، ولم تذكر الرّماح، قلت خِطيّة بكسر الخاء، كما قالوا: ثياب قِبْطيّة، فإذا جعلوه اسماً واحداً قالوا: ثُبْطيّة بضم القاف، فيغيّروا اللفظ، وامرأة قِبطيّة

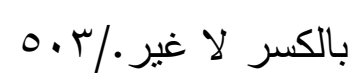

قرى عربية:(على الإضافة):لا تتصرف،وعربيةمنسوبة إلى العرب./9 بو 9

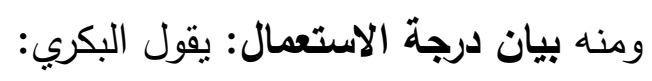

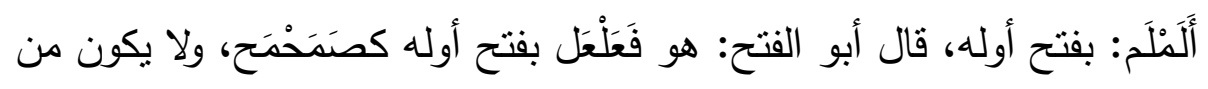
لفظ لَمَلَمَت لأن ذوات الأربعة، لا تلحقها زيادة إلا في الأسماء الجارية

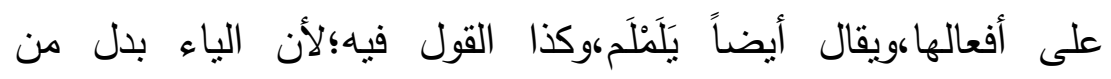




$$
\text { الهمزة./AV }
$$

أوْرَان: بفتح أوله، وإسكان ثانيه، وبالراء المهملة على وزن فَعْلان، أو أفعال،

قال ابن قتيبة قال الأصمعي: وبعضهم يخطئ فيقول: ذَزْوَان./ I)

أَوْقَضَى : بفتح أوله، وبالقاف، والضاد المعجمة، على مثال: أَفْعَلى، على أن

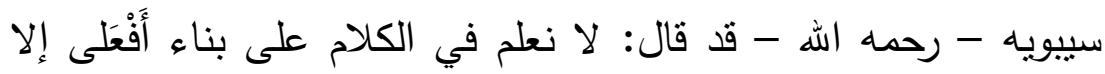

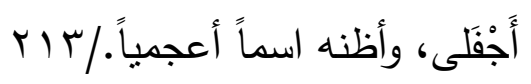

\section{ومنه بيان المفرد والمثنى والجمع:}

الخرطومتان: بضم أوله، وإسكان ثانيه، وباطاء المهملة على وزن تثنيته./؟ 9 ؟

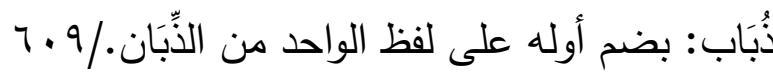

الذنائب: بفتح أوله، على لفظ جمع ذِنَابة. 10\%

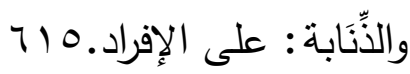

بيان الجنس من حيث التنكير والتأنيث:

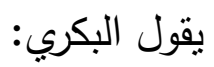

دَابِق: بكسر الباء... تذكر وتؤنث، فمن ذكّره جعله اسماً للنهر، ومن أنثه قال

$$
\text { هو اسم للمدينة./ }
$$

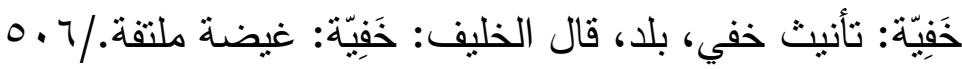

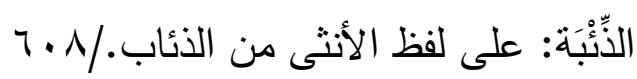

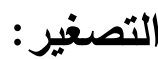

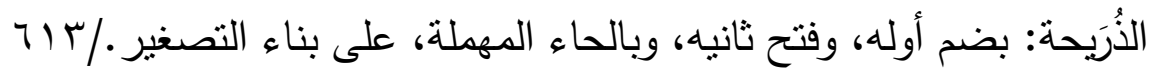

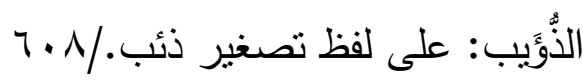

اللُّيَين: بضم أوله على تصغير لبن. 10 10

بيان اللغات:

يقول البكري: بَغْدَاد فيها أربع لغات: 
بغداد: بدالين مهملتين

بغداذ: معجمة الأخيرة

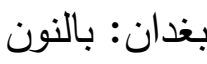

مَغْدَان: بالميم بدلاً من الباء، تذكر وتؤنتث. (1)

وفي زمزم يقول البكري: فيها لغات:

زَمْزَم: زَمْزَم، بفتح أوله، واسكان ثنانيه، وفتح الزاي الثانبة.

وزُمَزْم: بضم أوله، وفتح ثاينه، وكسر الزاي الثانية.

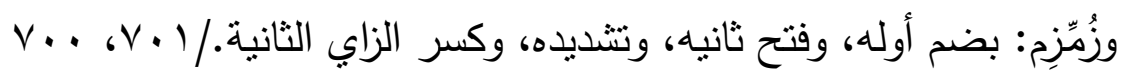

\section{الفصل الثاني: وسائل التعريف التي تتعلق بمعنى اللفظ:}

يتخذ شرح المعنى عند القدماء من أصحاب المعاجم (') سبلاً منها الثرح

بالتعربف بالألفاظ، ويُلحظ استخدامهم للألفاظ الواضحة، والألفاظ الغامضة -

في شروحهم - على حدّ سواء. والبكري يهنمّ بشرح معنى المدخل في معجمه

على نحو اهتمامه بمبناه، فالضبط عنده كل لا يتجزّأ، ولذا يتخذ من شرح المعنى بالتعريف بالألفاظ وسيلة، للتعريف بمداخل معجمه، ومن خلال قراءة مادته، لا يجد الباحث غموضاً في الألفاظ التي يعرّف بها - وإن كانت هذه بـ بـان الألفاظ عند غيره فيها غموض - وذلك لتكاتف وسائل الثرح والتوضيح لها من جهة، والاستشهاد والتوثيق من جهة أخرى، والدقة في استقاء المعلومة، والإحالة إلى مصادرها، ونسبتها إلى مظانها من جهة ثالثة. وبالنظر إلى صنيعه في مادته المعجمية - فيما يختص بالمعنى - يمكن

القول إن البكريّ يتخذ في شرح معاني مداخل معجمه سبيلين:

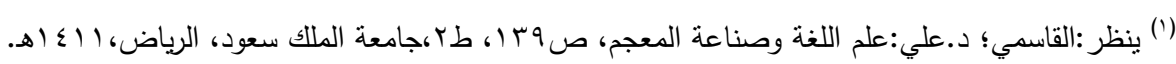




\section{الأول: شرح المعنى بالتعريف بالألفاظ. والثاني: شرح المعنى مقترناً بالثاهد. \\ الخطوات الإجرائية المتعلقة بشرح المعنى: \\ المبحث الأول: الشرح بالتعريف بالألقاظ:}

استعمال كلمة ضد: وقلّ استعمال البكري لها، وذلك عائد لطبيعة الحقل

الدلالي الذي يتتاوله، فهو يتحدث عن أسماء مواضع وأماكن.

ورد استعمال كلمة ضد عند البكري في قوله:

رأس الأبيض: يقول البكري: الأبيض ضد الأسود./r Tr

استعمال كلمة معروف: وردت عن البكري كثيراً وترددت في معظم الأماكن التي تحدث عنها، وقلّ عدم استعمالها عنده. من أمنلة استعماله لها:

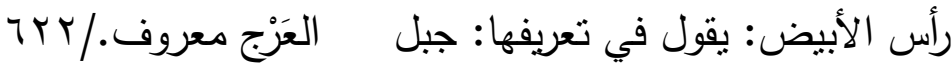
ويقول: مَزج الصَّفَّر: بضم أوله،وتتنديد ثنانيه وفتحه،بعد راء مهملة:موضع

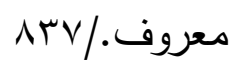

صَفُْرِيَة: بفتح أوله، وضم ثانيه، وتثديده، وكسر الراء المهملة، وتخفيف الياء

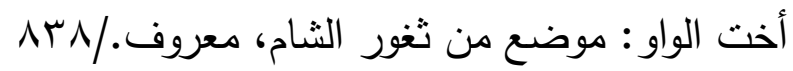

\section{التعريف بألفاظ محسوسة:}

تتوّعت وسائل البكري في استعمال عباراته في التعريف بمداخل معجمه،

ما بين العبارات المعنوية، والعبارات المحسوسة، فانصب اهتمامه على التعريف بالمحسوس وهذا يتتاسب مع حرصه ودقته في الضبط، بل إنه يخدم الغاية التي ينثدها في بناء معجمه، (ضبط النطق، وتوضيح المعنى) وفي ذلك يقول:

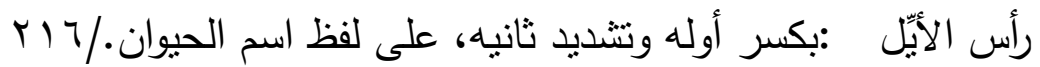


رأس العين :على لفظ عين الماء./rr الرَّاحتان :على لفظ تثنية راحة البد./\%

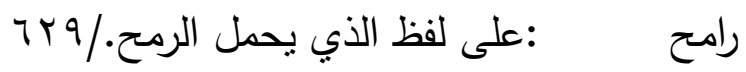
الرَّغام :بضم أوله على لفظ اسم التراب.

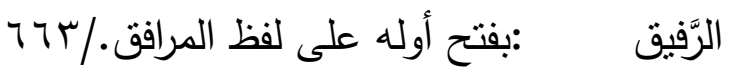
:وتتجلى براعته في التعريف بالمحسوس في تعريفه لـ رُمح،

$$
\text { ورامح، يقول في رمح: }
$$

رُمْح: بضم أوله على لفظ المحمول، وهو جبل في بلاد بني كلاب./VT رامح:نعلى لفظ الذي بحمل الرمح./9 7

\section{التعريف بألفاظ: أرض، بلد، بلاد، ثنبة، جبل، حصن، حرّة، جوية،}

الكور، كورة، مدينة، مسبل - هضبةة، موضع....

تمنّك هذه الألفاظ المصطلحات التي يقوم علبها معجم ما استعجم، فجميع ألفاظ مداخله أسماء مواضع، وأماكن، واستخدام هذه الألفاظ أساس يقوم عله الحقل الدلالي الذي يجمع ألفاظ معجمه، في حين بستدعي استعمالها في المعاجم العربية، الاتهام بعدم الدقة، والابتعاد عن صفات المعجم الجيد('). تتخذ هذه الألفاظ صفة الوضوح عند البكري في التعربف بها لمداخل معجمه؛ لأن معجمه مما يختص بها فهي لازمة من لوازمه، فهو معجم لأسماء البلاد والمواضع، وهذا أمر، الأمر الثاني الدقة الفائقة التي التزمها البكري في طريقة تعريفه بألفاظ معجمه فهو يحدد الموضع ويوثقّه بالثواهد، التي تربطه بأحداث أو مناسبات، من أيام العرب، وحروبهم، ومساكن قبائلهم وحدودها، فجاءت واضحة معروفة، من أمثلة ذلك: يقول البكري:

(1) ينظر :أنيس، د.إبراهيم، دلالة الألفاظ، ص9 ؟r، طء، مكتبة الأنجلو المصرية، .91 ام. IVT 
أَوْرَال: بفتح أوله، وإسكان ثانيه، وفتح الراء المهملة، على لفظ جمع ورل: ضَفِرَةٌ

$$
\text { دون مكة./1) }
$$

أَوْرَان: بفتح أوله، وإسكان ثانيه، وبالراء المهملة، على وزن فَعْلان، أو أفعال،

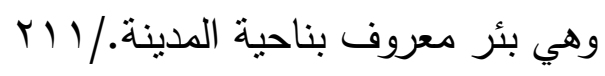

أَوْق: بفتح أوله، وإسكان ثانيه، وبالقاف، موضع بالبادية في ديار جعدة، تلقاء

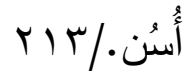

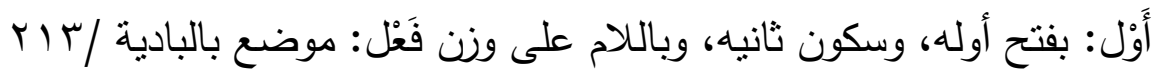

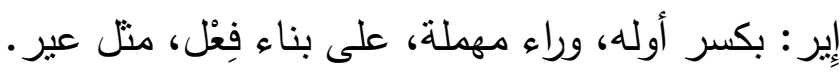

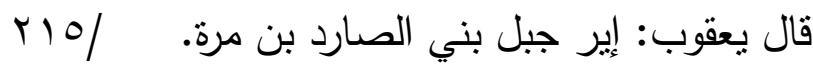
ذَمَار :بفتح أوله وثانيه، والراء المهملة مكسورة، اسم مبني، وهي مدينة باليمن

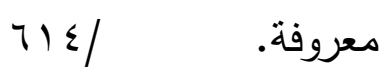

والذَّمَار : على مثال لفظه، بزيادة الألف واللام: بلد بحضرموت، ينسب إليه،

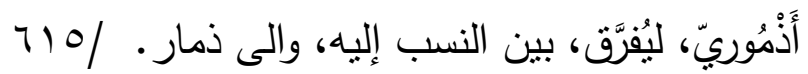

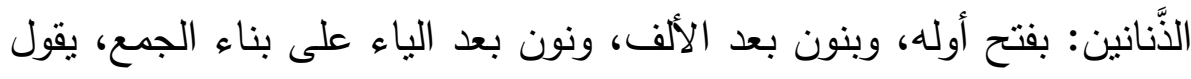
البكري: هكذا نقلته من خط عبداله بن حسين بن عاصم اللغوي، وهو ماء

$$
\text { من مياه ماويّه باليمن. /9 / } 19
$$

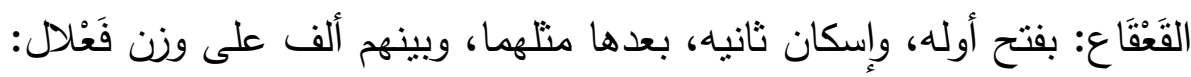

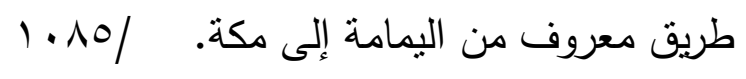

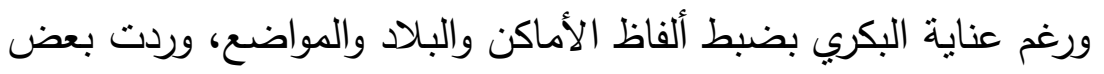

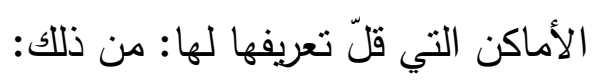

ذَهْوَط: بفتح أوله وإسكان ثنانيه، بعده واو مفتوحة وطاء مهملة: موضع ذكره

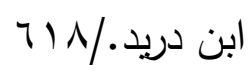

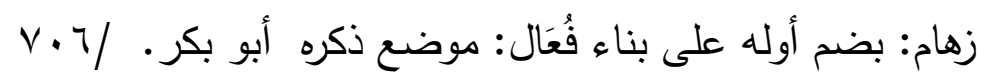


الزَواخي: بفتح أوله، وبالواو، والخاء المعجمة، على وزن فواعل: موضع ذكره

$$
\begin{aligned}
& \text { أبو بكر رحمه الله./T V V }
\end{aligned}
$$

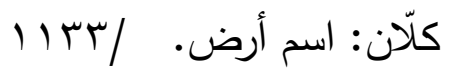

ويبدو من عزوه لها: أنه نلقها أو سمعها وهو لا يعرفها. التعريف بالعبارة المتلازمة 》التضامهي:

يقصد بالمتلازمات الوحدة المركبة من لفظين يمكن أن يستقل كل منهما

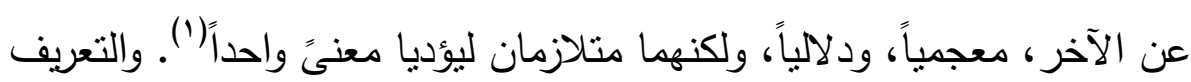

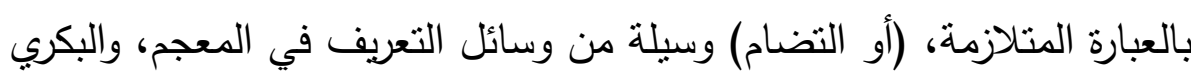

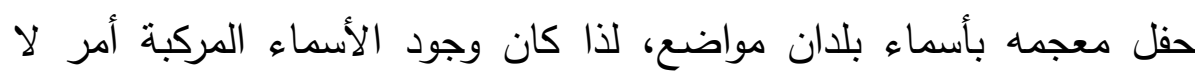
مناص منه، فكان سبيله في التعريف (بهذه الأسماء المركبة)، التعريف بالعبارة المتلازمةة، باعتبارها كلمة واحدة، فمن ذلك: أحجار الزيت: جمع حَجَر، منسوبة إلى الزيت الذي يؤتدم به: موضع متصل

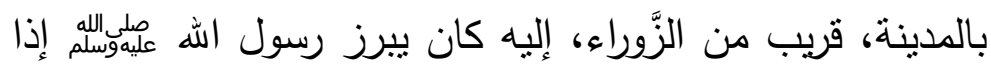

$$
\text { استسقى./ }
$$

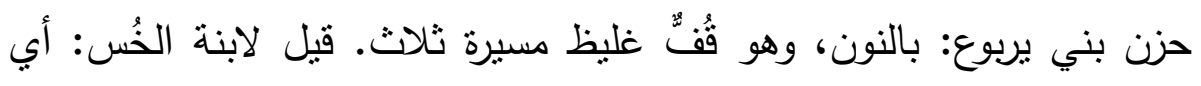

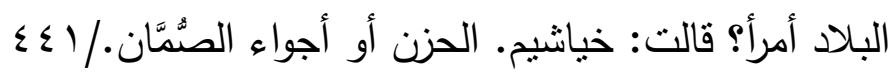

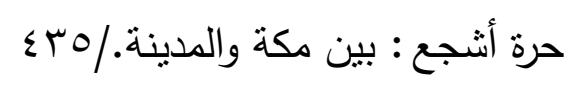

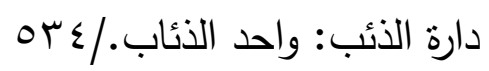$$
\text { دير حنظلة: دير بالجزيرة./ }
$$

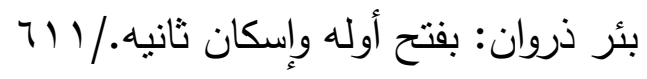

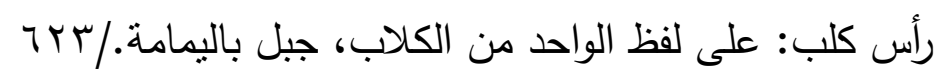

(1) ينظر : الأقطش؛ عبدالحميد، محاضرات في نصوص اللغة، جامعة أم القرى. 


$$
\text { ديار ربيعة: تضم عدة كور .071 }
$$

جرعاء العجوز : موقع، قال ذو الرمة:

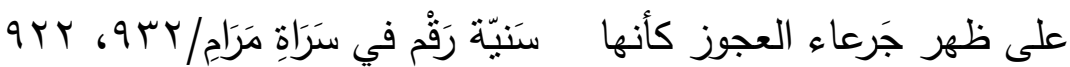
عرق الظبية:موضع بالصفراء قد تقدم ذكره في حرف الظاء./؟ ب9(يظظر r.9). عقبة المرَّان: قد تقدم ذكرها في حرف الميم وهي عقبة مشرفة على غوطة

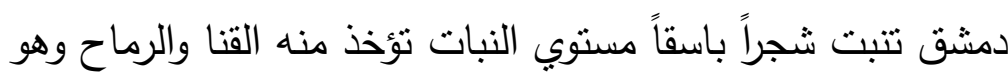

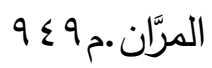

كَفْرُ شيلان: بكسر الثين المعجمة، بعدها الياء أخت الواو : بالثام منه أحمد

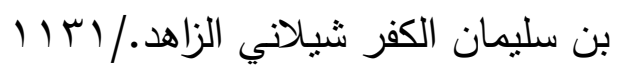

كفر عاقب: بالعين المهملة والقاف المكسورة والباء المعجمة بواحدة، وهو تلقاء طبريه، وإياه عنى أحمد بن الحسين بقوله:

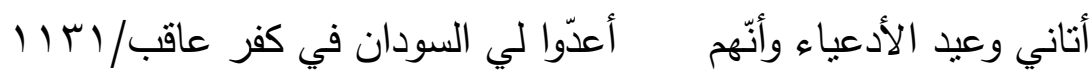

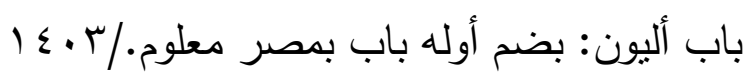

\section{التعريف بالشرح بالإحالة:}

الإحالة تركيب لغوي يشير إلى (جزء ما) ذُكر صراحة أو ضمناً في النص الذي سبقه، كما تثير إلى عملية استرجاع المعنى الإحالي في الخطاب مرة أخرى، فيقع التماسك عبر استمرارية المعنى ('). ومن وسائل التعريف عند البكري التعريف بالإحالة، أو (ما يعرف بالثرح الدوّار)، فيكثر في مادته قوله مذكورة في رسم كذا، وبالرجوع إليها يُلاحظ ارتباطها بالمادة التي أحيلت إليها، إما (بسبب المكان): تجاور أو اتصال طريق، (وإما بسبب القبائل) مساكنهم، وإما لارتباطها بمناسبة لامعركة، حادثة،

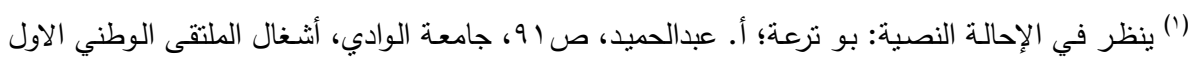

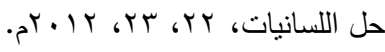


قصة..." وإما اشتراك في ذكرها في الثاهد الثعري الذي يرتبط بأمرٍ بنلك

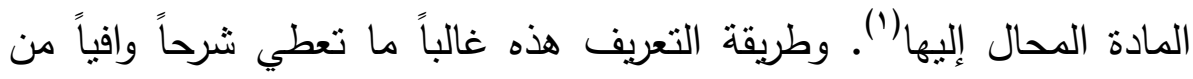
حيث التعريف كما أنها تضفي نوعاً من الحيوية في سرد الألفاظ، وتثري التقافة

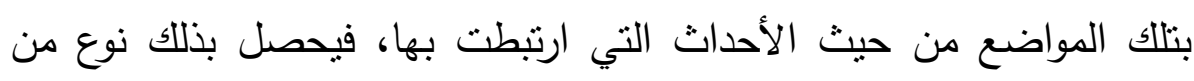
التثقيف، وفي ذلك نوثيث للتعريف بذكر الأحداث التي ارتبطت به، ومصداقية في المعلومات المذكورة.

\section{ومما ذكره البكري في هذا الخصوص:}

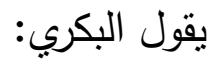

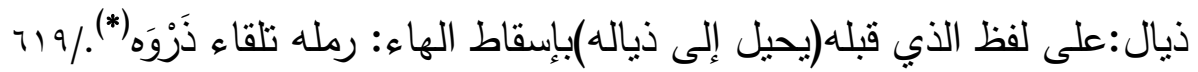

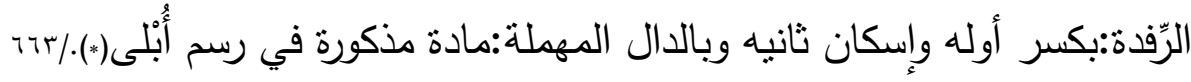
دارش:بكسر الراء، وبالثين المعجمة:موضع مذكور في رسم مَسْرُقان(*).//r هـ

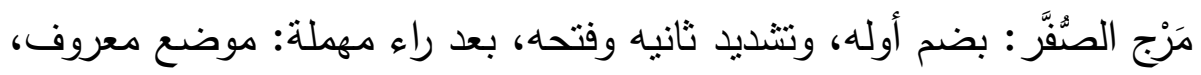

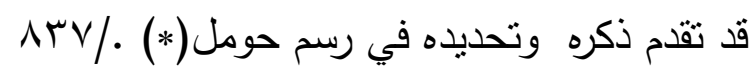

الصُُفَْة: بضم أوله، وإسكان ثانيه، بعده قاف وهاء التأنيث، مادة مذكورة في

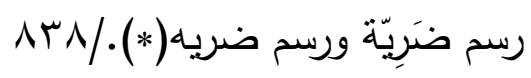

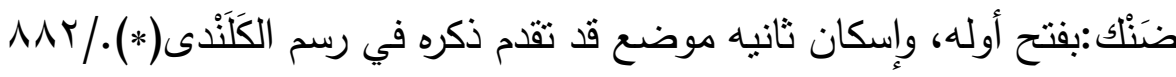

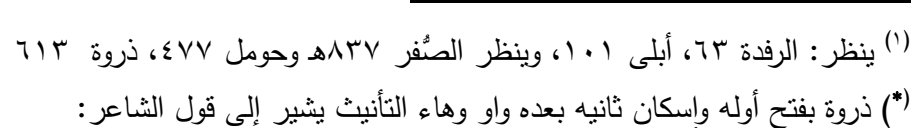

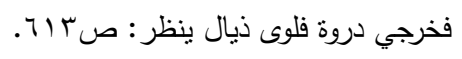

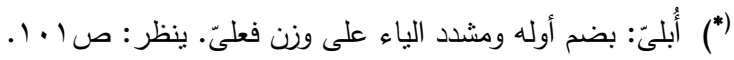

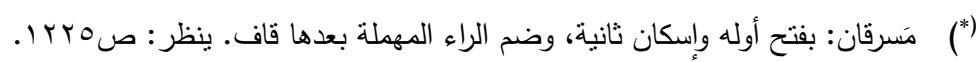

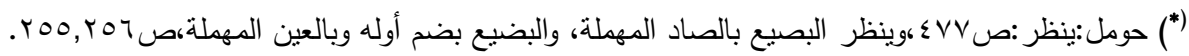

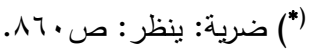

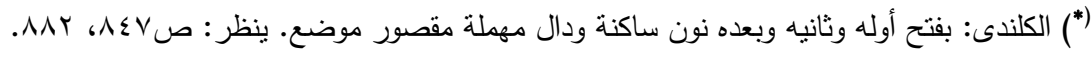




\section{المبحث الثاني: الشرح بالتعريف مقترناً بالشاهد:}

الثواهد: جمع شاهد، يقصد به: العبارة الكلية التي يمكن أن تكون في هيئة شعر أو آية قرآنية أو حديث شريف أو قول مأثور • ويعنون بمصطلح الثاهد،(أو ما يعرف بعربية الاستشهاد) إلى النصوص اللغوية التي أقيمت اللغة على أساسها ومنوالها في عصر التدوين، فسمي الكلام في هذه المرحلة شواهد (rv). (rv).

انعكست مدونة البكري الثقافية واللغوية على مادته المعجمية، فجاءت

غنية بوسائل التعريف المختلفة. وكان التعريف مقترناً بالثاهد، غاية ما انتهت إليه منهجية البكري في الضبط. يقول د.علي القاسمي: اوتستعمل الثواهد في المعجم لتبرهن على أن كلمة أو معنىً معيناً من معانيها موجودة أو موجود فعلاً في اللغةة" ('). ومن خلال قراءة معجم ما استعجم، يلحظ أنه لا توجد لفظة ارتبطت بأثز إلا وذكره، فنتوعت شواهد احتجاجه، في شرح معاني ألفاظه، سواء كان ذلك الاحتجاج بالقرآن الكريم، أو الاحتجاج بالحديث، أو الاحتجاج بالثعر أو الاحتجاج بالمثل أو الاحتجاج بالخبر • وفيما يلي تفصيل ذللك: الخطوات الإجرائية لشرح المعنى بالتعريف مقترناً بالشاهد: أ - الاحتجاج بالقرآن الكريم:

البكري شديد العناية بالضبط لذا لم ترد لفظة في معجمه إلا وكان لها من وسائل التعريف الثيء الكثير وكان الثاهد (ما وجد إلبه سبيلاً)، مقترناً

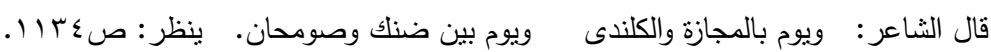

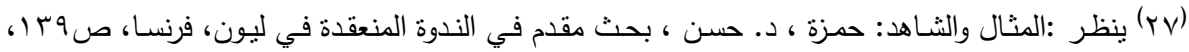
طץ، جامعة الملك سعود، الرياض ، 11 الإلهـ

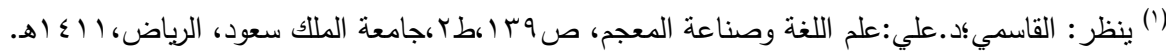


بالتعريف لا يفارقه، فمن ألفاظه التي احتج لها بالثاهد القرآني: إرم ذات العماد: بكسر أوله، ويقال إنها دمشق، وإن بها أربع مئة ألف عمود من حجارة. ويقال: إن إرم ذا العماد بتيه أبين من اليمن وبهذا التيه سكن إرم بين سام بن وإن إنها

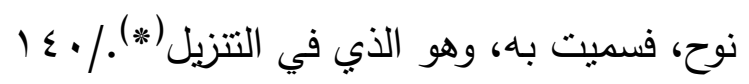

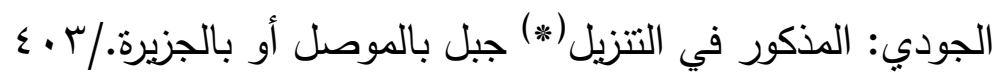

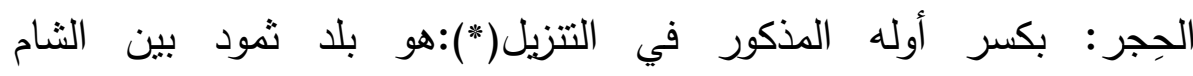
والحجاز ./.

طوى: بضم أوله وكسره مقصورة: اسم واد في أصل الطور بالثام، وهو المذكور في التنزيل(*)./.

الطور: جبل المقد ممتد ما بين مصر وأيلة، سمي بطور إسماعيل بن

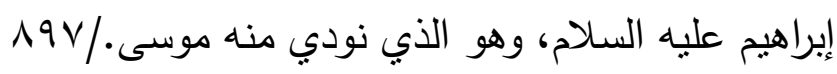

قال تعالى: وما كنت بجانب الطور إذ نادينا"/القصص(من آية 7ــ). وهو طور سيناء، قال الله سبحانه:"وشجرة تخرج من طور سينا تَتَبْتُُ/المؤمنون(من

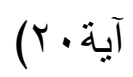

وقال في موضع آخر من كتابه:"والتين والزيتون وطور سينين".التين(من آيةץ)

\section{ب - الاحتجاج بالحديث الشريف:}

الصَّفراء:على لفظ تأنيث أصفر: قرية فوق يَنْعُ. ومن حديث أبي سلمة عن عائشة قالت: خرجا مع رسول الله صلى الله عليه وسلم في غزوة بدر لئر الأخيرة، حتى إذا كنا بالأثيل عند الصفراء بين ظهراني الأرالك، قال لي:

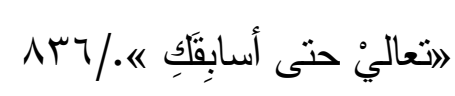

صفُورِية: بفتح أوله وضم ثانيه وتتديده وكسر الراء المهملة وتخفيف الباء أخت

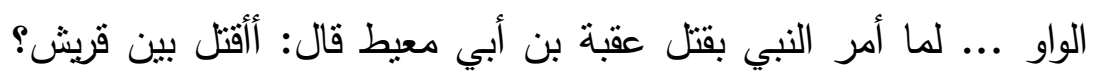


فقال له النبي صلى الله عليه وسلم:اوهل أنت إلا يهودي من يهود صَفْوريةنه/.

وَرِقان: بفتح أوله وكسر ثنانيه بعده قاف على وزن فَعِلان: وهو من جبال تهامة... يقول البكري ومن حديث وهب... عن أبي سعيد الخدري، قال: قال رسول الله صلى الله عليه وسلم: ارقعد الكافر من النار مسيرة ثلاثة أيام، وضرسه منل أحد، وفخذه منل ورقا نش. ITVV وادي الأزرق: بالراء المهملة عبد الزاي ثم قاف، أفعل من الزرقة، وهو خلف أحج وفه إلى مكة بميل. ومن حديث بن عباس أن رسول الله صلى الله عليه وسلم

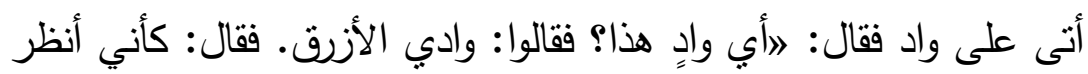

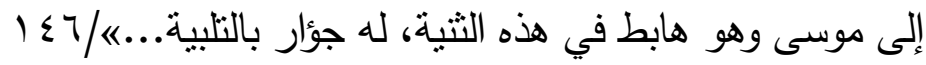
ج - الاحتجاج بالشعر: يقول البكري: قال أبو عبيدة: إسبيل: جبل باليمن، وأنثد للنمر بن تولب:

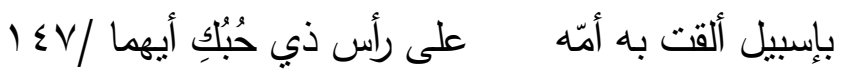
يقول البكري في إير : بكسر أوله وراء مهملة على بناء فِعْل منل عير ، قال بعقوب:

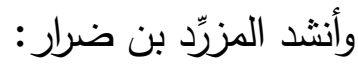

فإنه بكندير حمار ابن واقع رآلك باير فاشتأى من عُنائد قال وعتائد: هِضابُّ أسفل من إير لبني مُرَة.

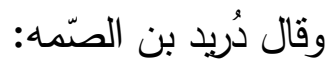

ذريني أطوف في البلاد لعلي ألاقي بإير تلأة من محارب/0 إن يقول البكري: فدل قول دريد هذا، أن إيراً من ديار محارب. دارش: بكسر الراء، وبالثنين المعجمة. وهو الذي عنى أبو الطيب بقوله:

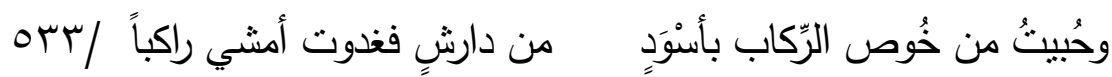


دابق :بكسر الباء... يقول البكري: تذكر، وتؤنث. فمن ذكره جعله اسماً للنهر، ومن أنثـ قال هو اسم المدينة. فال الثاعر في الإجراء على التذكير: بدابقٍ وأين مني دابقُ وقال آخر في التأنيث وترك الإجراء:

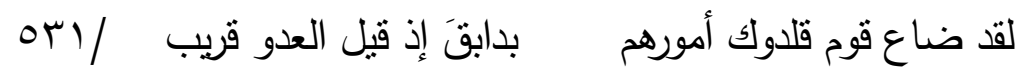
الظُّربية: بضم أوله، وفتح ثانيه،على لفظ التصغير، كأنه تصغير ظربة: موضع بالثنام.

وقال إسحاق:هو موضع بناحية الطائف، كان لسعيد بن العاصي فيه مال، وأورد قول ابنه إبان:

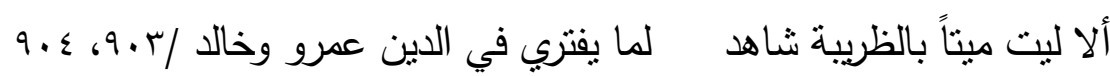
د - الاحتجاج بالمثل السائر:

المثل مصطلح يراد به الحكمة والأفوال المأثورة التي قيلت في مناسبات معينة وجرى قبول هذا المنل في العُرف فحفظ بتركيبه لا يزاد فيه ولا ينقص منه، بها،

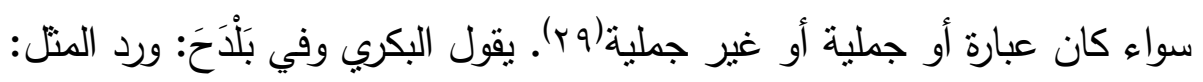

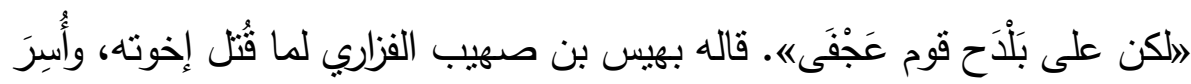
هو

جوف: بفتح أوله، وبالفاء أخت القاف موضع باليمن، وهو جوف حمار ، منسوب إلى حمار بن مويلع، من بقايا عاد، أشرك باله، وتمرّد، فأرسل الله عليه ناراً

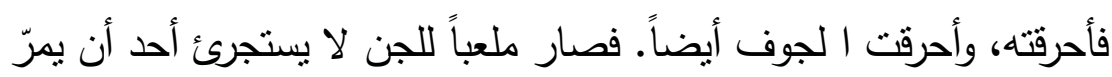
به، والعرب تضرب به المثل فتقول: أخلى من جوف حمار، وقال ابن قتنية هو جوف مراد، وإياه عنى امرؤ القيس بقوله: ووادٍٍ كجوف العَبْر ققر قطعتهه به الذئب يعوي كالخليع المعيّل 
يقول البكري: أراد جوف حمار فلم يستقم له الثعر فقال كجوف العَيْر. دير كعب :بالثام وهو الذي جاء فيه المنل: „أطول من فراسخ دير كعبه. قال الثاعر:

\section{ذهبت نمادياً، وذهبت عرضا كأنك من فراسخ دير كعب}

ولم يكتق البكري بتتوع وسائل التعريف في معجمه، فقد كان يذكر المواضع وكل ما حدث فيها من أخبار وقصص ارتبطت بنلاك المواضع("). فنشكل معجم ما استعجم وما حواه من مادة موسوعة معجمية في البلدان والأخبار والأحداث. فخرج المعجم من جمود اللغة إلى بعث الحياة داخلها من خلال مواكبة اللغة للحدث.

اعتمد البكري في الجانب التحليلي لمادته المعجمية على الثرح بالتعريف بكافة صوره، وكانت وسائله كثيرة ومتعددة طبقها على جميع مواد المعجم، إلا

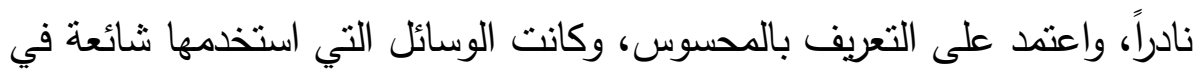
كل مواد المعجم، والتزام فنية ضبط الرسم ثم شرحه والطرق المتعلقة بالمبنى، ثم المعني، ثم يقرن ذلك بالثاهد معزواً لصاحبه، مما يجعل العمل المعجمي الذي قام به، على درجة عالية من المصداقية العلمية، التي يتحراها مستخدم المعجم أو الباحث اللغوي.

\section{الفصل الثالث: المقاربة السيمية والترابط المعجمي:}

يهذف هذا الفصل إلى توضيح المعلومات التي قدمها البكري من خلاله

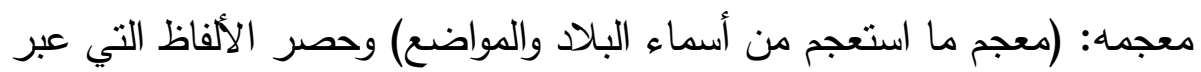
بها في شرحه، ثم تحديد مدلولاتها وبيان دلالتها والعلاقة بينها، والترابط بين التراكيب والعناصر اللغوية المختلفة التي تتكل وحدة متآلفة، يترتب عليها التماسك بين الأجزاء المشكلة للنص المعجمي. باعتبار معجم ما استعجم نصاً 
لغوياً مترابطاً من نواحٍ عدة، وذلك من خلا الحقل الدلالي وعناصر الاتساق.

\section{المبحث الأول: الحقل الدلالي عند البكري في معجم ما استعجم:}

يقصد بالحقل الدلالي: المقاربة السيمية التي تهدف إلى دراسة المداخل التي

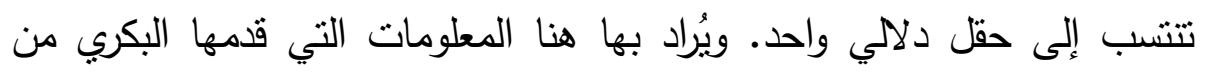
خلا كتابه 》معجم ما استعجم من أسماء البلاد والمواضع). والتي عبرّ عنها في إجمال الحديث عن موضوع كتابه، في المقدمة، حيث يقول:هذا كتاب ذكرت فيه

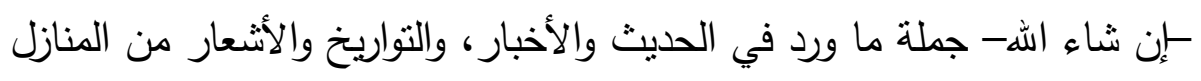

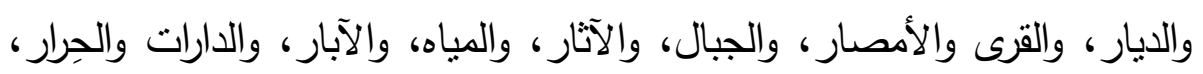

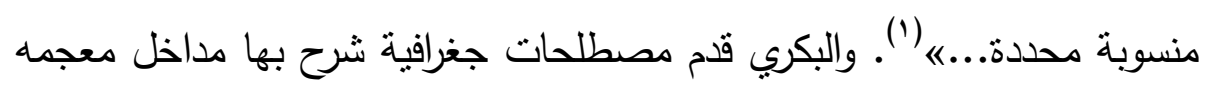
تظهر ملامح التصور الجغرافي عند البكري. والدراسة الدلالية ينبغي أن تقوم على حصر الألفاظ التي عبر بها في شرحه، ثم تحديد مدلولاتها وبيان دلالتها على الأجناس الجغرافية وتوضيح العلاقة لإنة بينها. ومحدودية هذه الدراسة لا تسمح بهذا التتاول إلا في حدود التحليل الذي يخدم الدراسة، لذا سيككتَى فيه بذكر ارتباط المداخل بالحقل الدلالي في معجم البكري وهو على النحو التالي: التئ

تعددت المجالات الدلالية للألفاظ التي شرح بها البكري مداخل معجمه، فبلغت سبع حقول لا تخرج بها عن الحقل الأساسي، وهو حقل المصطلحات الجغرافية. ويمكن اعتبار تتوعها، تتوعاً في المباحث الجغرافية، على مذهب البكري في تتوع وسائل تعريفه. وهذه المباحث يمكن تصنيف بعضها تحت حقل الجغرافيا الطبيعية وهي:

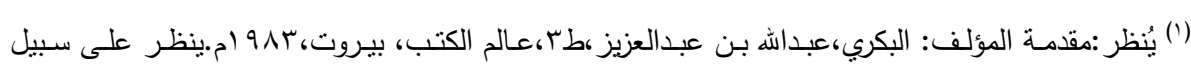

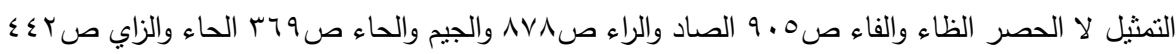




$$
\text { 1- الألفاظ العامة 》أرض، مكان، موضع). }
$$

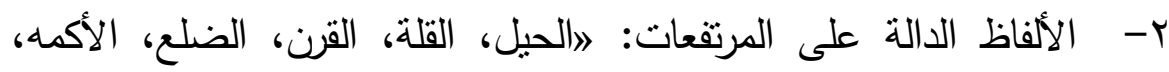
القفّ، الثشرف، الهضبة، الحرّة، القَنة، الرملة، الحجر، الكثيب.... الخ «.

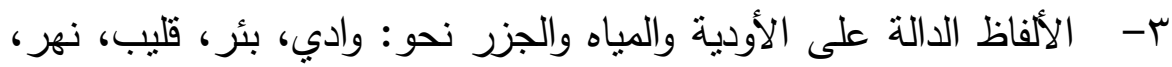
ماء، مسيل، غدير ، حساء، ساحل، سيف، مرفأ... الخ.

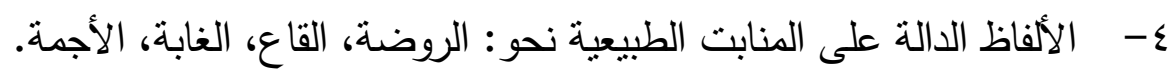
ومما يمكن تصنيفه تحت حقل جغرافية العمران أو المدن: 1- الألفاظ الدالة على البلدان ومناطق العمران نحو:بلد، مدينة، قرية، كوره، كفر . ץ-الألفاظ الدالة على المساكن والديار نحو: دار، منزل، داره، قصر ، حصن،

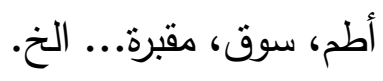

ץ- الألفاظ الدالة على الطرق نحو: طريق، ثنية، دحل، درب، فأو ... ويمكن إدراج :ساحل،وسيف،مرفأرتحت حقل جغرافيةالنقل أو الجغرافيا الاقتصادية. ومن خلال الحقل الدلالي يمكن الوقوف على ملامح التصور الجغرافي عند واحد من علماء الجغرافيا العربية الذي ثُظهر هذه الدراسة ملمحاً من ملامحه، وهي لوهي

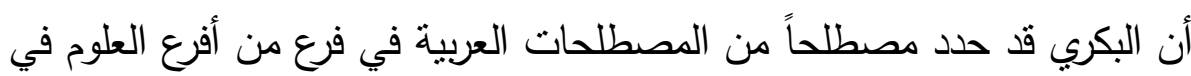
عصر من العصور ، كما أحل ألفاظاً غير عربية نحو: كورة والتي أصلها يوناني، وكفر وأصلها سرياني، وزرادق وطوج، وأصلهما فارسي، وقد رغبت العربية عن استخدامها اليوم ولم ييق منها إلا كفر المستخدمة في مصر • أما العلاقات الدلالية بين الألفاظ الجغرافية في إطار مجالاتها الدلالية فإن أبرزها: علاقة الترادف :بئر، قليب - وهذا عائد لاختلاف البيئة اللغوية. بلد، كورة، من باب التعارض المجمعي.

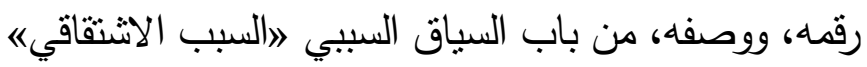


علاقة العموم والخصوص: الوادي، الثعب، ولعل ما ذكر يُغني عما نرك للقارئ المتخصص.

\section{المبحث الثاني :عناصر الاتساق في معجم ما استعجم:}

يقصد بالاتساق: الترابط بين التراكيب والعناصر اللغوية المختلفة... لتشكل وحدة

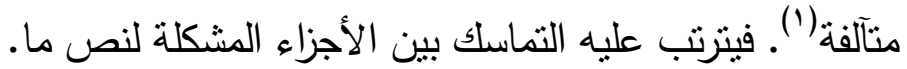
ومعجم ما استعجم يعتبر نصاً لغوياً مترابطاً من نواجِ عدة:

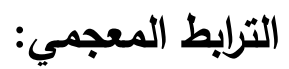

ويظهر من خلال انتمائه إلى حقل دلالي واحد هو حقل المصطلحات الجغرافية، فالمداخل تتكرر بشكل منوازٍ، متصاحب، فلا توجد لفظة - ناشزة عن

$$
\text { موضوع النص - لا ترتبط به (؟) }
$$

ويراد به نوعية العبارات التي استخدمها المؤلف في شرح مادته المعجمية. البكري من خلال شرحه لمواد معجمه يستخدم الجمل القصيرة، التي تتنمي إلى عالم المحسوسات أحياناً، ويوظفها في تتظيم صحة النطق والضبط اللغوي لني توظيفاً جيداً، فبعد الضبط بالرسم، يليه الضبط بالمنال حيث يستخدم الوزن

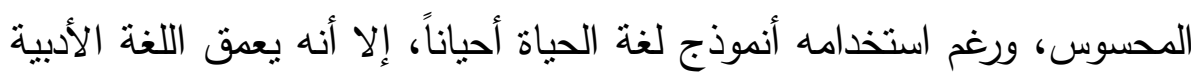
بتكريس نماذج الحياة؛ لأن لغة الحياة ولغة الأدب في زمنه واحدة.

(') ينظر : سعدية، نعيمة، مقالة: الاتساق النصي في التراث العربي، جامعة محمد خيضر ، مجلة كلية الآداب

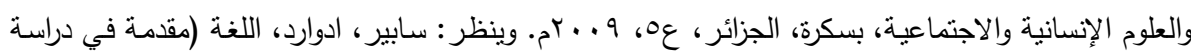

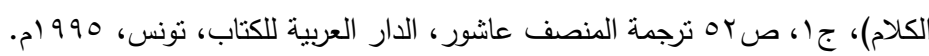

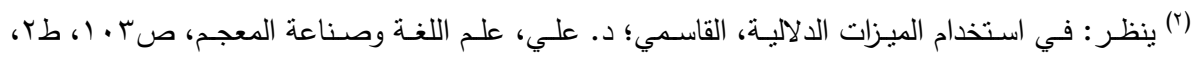

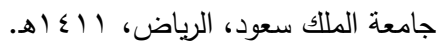




\section{الروابط المنطقية:}

هي روابط غير لغوية تقيد في تحليل وفهم النص، وهي وسائل من وسائل التعريف عند البكري، حيث أنه: تعريف خارج عن اللغة يعتمد المنطق، فهو يصنف الكلمات بحسب المحسوس، والمجرد، وكثيراً ما يفسر المدخل بمجمل أو لون بنصّ يصف مضمونها من دون أن يعرفها لغوياً('). نحو : رمح، رامح (). ويُقصد بالروابط المنطقية عند البكري: الأحداث والمناسبات التي ارتبطت بموضع أو مكان المناسبة، ويعتمد البكري من هذه الناحية على القصص، والآثار والحوادث التي تُعين على التعريف بالموضع لارتباطه بنلك المناسبة. المقامية:

ويُقصد بها اختيار اللغة التي تتناسب مع الواقع الجغرافي والتقافي، ويعتمد البكري على المقامية بشكل كبير لأن معجمه يُعد معجماً لغوياً خاصاً يتضح ذلك لك لهي من خلال لغة المعجم وشواهده. فهو يختار لغة عُليا، تتتاسب مع الزمن الذي صنع فيه معجمه، كما نتتاسب مع سياق موضوع معجمه، وهو ضبط نطق

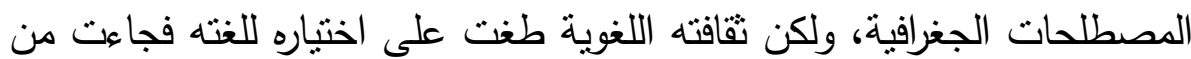
وجهة اللغة، أكثر من وجهة علم الجغرافيا. ولعل ما يشفع له هو الزمن الذي صنع

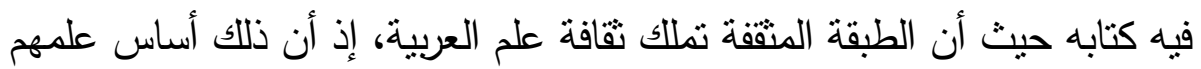

$$
\text { آياً كانت مجالات علومهم. }
$$

الغاية من معجم البكري هي ضبط المصطلحات الجغرافية، وأمن اللبس في نطقها،والباحث في الكتاب يلمس جه البكري في تحديد الأماكن،ووصفها، وضبط

$$
\begin{aligned}
& \text { (") ينظر : التعريف المنطقي: الحمزاوي، د. محمد رشـاد: من قضـايا المعجم العربي، صبه ا، طا، دار } \\
& \text { الغرب الإنلامي، بيروت، }
\end{aligned}
$$

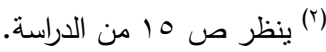


مسمياتها، وتوثثقها، بشتى الوسائل، مما يشعره بمصداقية المعلومة، وقيمة الجها المبذول فيها، مما يولد لديه قبولاً لها. البؤزة:

يقصد بها الفكرة التي بنى عليها البكري معجمه، وأراد له أن يتميز بها

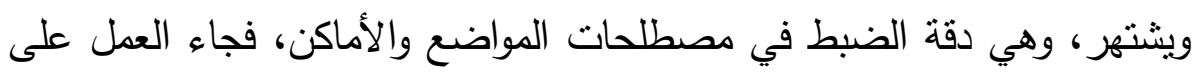
قار طموح صاحبه. التثاص: تتكيل نص جديد من نصوص سابقة لاوخلاصة لنصوص تماهت فيما بينها فلم ييق منها إلا الأثز، ولا يمكن إلا للقارئ النموذجي أن يكتشف الأصل،

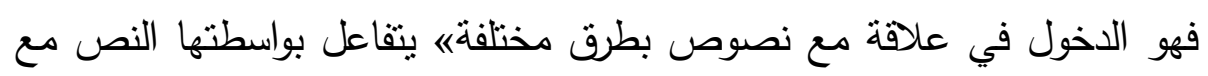
الماضي والحاضر والمستقبل ('). فهو قريب من الاقتباس والتضمين وليس منه فالتتاص أوسع.

ويعد:

فقد أجاد البكري كثيراً في ضبط وإتقان مادته المعجمية، ووسائله المتعددة في الضبط والتعريف، وسيلته في ذلك مدونته النقافية اللغوية العالية، حيث استتد

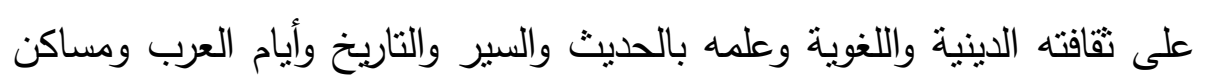

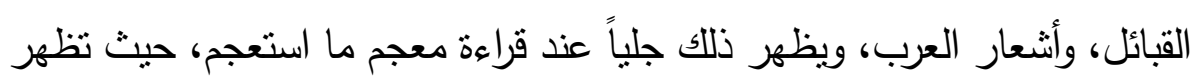
ثقافة البكري العالية والجامعة، فجاء معجم ما استعجم على قدر طموح صاحبه زاداً لغوياً، وأنموذجاً للرقي المعجمي العربي في تقنيات التعريف، الذي يضاهي فنيات وتقنيات المعجم المعاصر،هذه التقنيات والفنيات هي ما ذكرته الدراسة الحديثة،

(') ينظـر في مفهوم التتاص: المصطلح والإثـكالية: عزام، د. محمد: النقد والدلالـة: نحو تحليل سيميائي

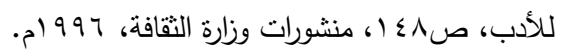


أرجو أن أكون قد وُفِّت في إبراز ملمح من ملامح عمل، أخلص فيه صاحبُه جدَّه، وحباه جُهُْهُ، وابتغى فيه إحدى الحسنيين: أجر العلم، وأجر العمل، سائلة العلي القدير بمنّه وفضله، أن يجعلنا وإياه ممن يتقبل عنهم

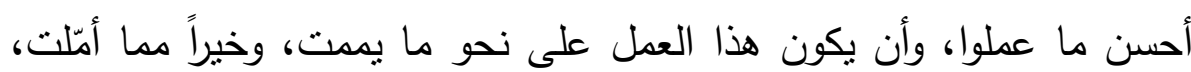

$$
\begin{aligned}
& \text { ״والحمد لله رب العالمينه } \\
& \text { وأن يقع موقع القبول. }
\end{aligned}
$$

\section{المراجع:}

1- تحليل المادة المعجمية: الثبيتي، د. محمد بن سعيد، الموسوعة الثاملة،

$$
\text { مجلة أم القرى، بدون بيانات. }
$$

r- تحليل النصوص،كنون،حسن،مجلة|لتسامح،بدون بيانات،الثبكة العنكبوتية r- تقنيات التعريف في المعاجم العربية المعاصرة: الجيلاني، حلام، جامعة

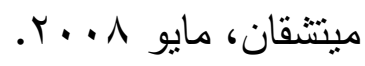

ع - دلالة الألفاظ: أنيس، د.إبراهيم، طع، مكتبة الأنجلو المصرية، . 91 ام. 0- علم اللغة وصناعة المعجم، القاسمي: د. علي، طب، جامعة الملك سعود،

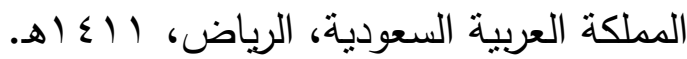
צ- في الإحالة النصية: بو ترعة، أ. عبدالحميد، جامعة الوادي، أثنغال الملتقى

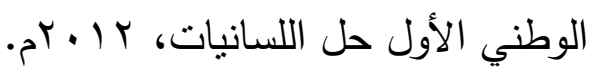
V- قلائد العقيان في محاسن الأعيان: للفتح بن حاقان (ت:0بهـهـ.

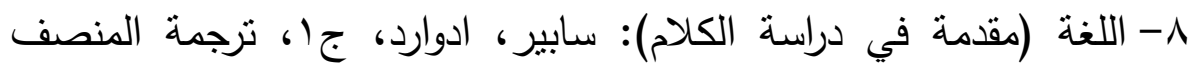


عاشور ، الدار العربية للكتاب، تونس، 990 (م. 9- اللغة العربية معناها ومبناها:حسان؛ تمام، طب، الهيئة المصرية العامة ل للكتاب 9 م

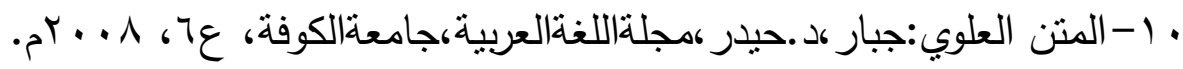
1 ا-المثال والثـاهد: حمزة، د. حسن ، بحث مقدم في الندوة المنعقدة في ليون،

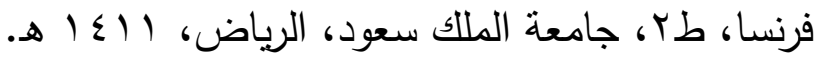
r ا-محاضرات في نصوص اللغة: الأقطش، عبدالحمبد، جامعة أم القرى. ب ا- المعاجم العربية: درويش؛ عبدالله، مكة المكرمة، الفيصلية، 7 ، ـ اهـ. ء ا-المعاجم اللغوبة في ضوء دراسات علم اللغة الحديث: أبو الفرج، محمد أحمد، طا (، دار النهضة العربية، 779 (م. 1 - المعاجم اللغوية:أبوالفرج محمد،أحمد،ط (، دار النهضة العربية، 797 (م. 7 ا- المعجم الوسيط: مجمع اللغة العربية، القاهرة، بدون تاريخ. IV - معجم ما استعجم من أسماء البلاد والمواضع:البكري،عبداله بن عبدالعزيز

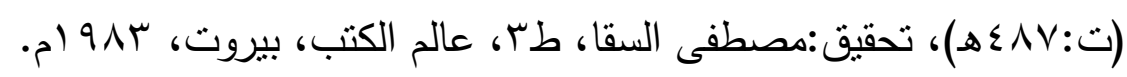
1 ا-مقالة الاتساق النصي في التراث العربي: سعدية، نعيمة، جامعة محمد خيضر ، مجلة كلية الآداب والعلوم الإنسانية والاجتماعية، بسكرة، الجزائر ،

$$
\cdot{ }^{3} \cdot 9 \text {. }
$$

9 1 -من قضايا المعجم العربي: الحمزاوي، د. محمد رشاد، طا، دار الغرب

$$
\text { الإسـامي، بيروت، } 919 \text { (م. }
$$

• ب- النقدوالدلالة:نحوتحليل سيمبائي لأدب:عزام،د.محمد،منشورات وزارة

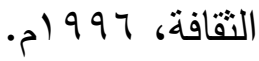

